\title{
Next Generation Probiotics for Neutralizing Obesogenic Effects: Taxa Culturing Searching Strategies
}

\author{
Ana López-Moreno $1,2, *,+\left(\mathbb{D}\right.$, Inmaculada Acuña $2,3,+\left(\mathbb{D}\right.$, Alfonso Torres-Sánchez $\left.{ }^{1, *} \mathbb{(}\right)$, Ángel Ruiz-Moreno ${ }^{1}(\mathbb{D}$,

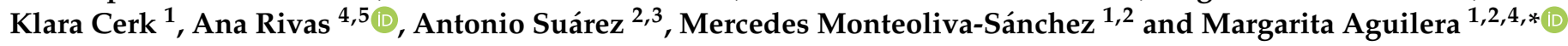 \\ 1 Department of Microbiology, Faculty of Pharmacy, Campus of Cartuja, University of Granada, \\ 18071 Granada, Spain; angel_trm_@hotmail.com (Á.R.-M.); klara.cerk@gmail.com (K.C.); \\ mmonteol@ugr.es (M.M.-S.) \\ 2 Center of Biomedical Research, Institute of Nutrition and Food Technology "José Mataix", \\ University of Granada, Armilla, 18016 Granada, Spain; iacuna@ugr.es (I.A.); asuarez@ugr.es (A.S.) \\ 3 Department of Biochemistry and Molecular Biology, Faculty of Pharmacy, Campus of Cartuja, \\ University of Granada, 18071 Granada, Spain \\ 4 IBS, Instituto de Investigación Biosanitaria, 18012 Granada, Spain; amrivas@ugr.es \\ 5 Department of Nutrition and Food Science, Campus of Cartuja, University of Granada, 18071 Granada, Spain \\ * Correspondence: alopezm@ugr.es (A.L.-M.); alfons_ats@hotmail.com (A.T.-S.); maguiler@ugr.es (M.A.); \\ Tel.: +34-9-5824-5129 (M.A.); Fax: +34-958-246235 (M.A.) \\ + These authors contributed equally to this work.
}

check for updates

Citation: López-Moreno, A.; Acuña, I.; Torres-Sánchez, A.; Ruiz-Moreno,

Á.; Cerk, K.; Rivas, A.; Suárez, A.;

Monteoliva-Sánchez, M.; Aguilera, M Next Generation Probiotics for Neutralizing Obesogenic Effects: Taxa Culturing Searching Strategies. Nutrients 2021, 13, 1617. https:// doi.org/10.3390/nu13051617

Academic Editor: Bengt Jeppsson

Received: 26 February 2021

Accepted: 8 May 2021

Published: 12 May 2021

Publisher's Note: MDPI stays neutral with regard to jurisdictional claims in published maps and institutional affiliations.

Copyright: (c) 2021 by the authors. Licensee MDPI, Basel, Switzerland. This article is an open access article distributed under the terms and conditions of the Creative Commons Attribution (CC BY) license (https:// creativecommons.org/licenses/by/ $4.0 /)$.

\begin{abstract}
The combination of diet, lifestyle, and the exposure to food obesogens categorized into "microbiota disrupting chemicals" (MDC) could determine obesogenic-related dysbiosis and modify the microbiota diversity that impacts on individual health-disease balances, inducing altered pathogenesis phenotypes. Specific, complementary, and combined treatments are needed to face these altered microbial patterns and the specific misbalances triggered. In this sense, searching for next-generation beneficial microbes or next-generation probiotics (NGP) by microbiota culturing, and focusing on their demonstrated, extensive scope and well-defined functions could contribute to counteracting and repairing the effects of obesogens. Therefore, this review presents a perspective through compiling information and key strategies for directed searching and culturing of NGP that could be administered for obesity and endocrine-related dysbiosis by (i) observing the differential abundance of specific microbiota taxa in obesity-related patients and analyzing their functional roles, (ii) developing microbiota-directed strategies for culturing these taxa groups, and (iii) applying the successful compiled criteria from recent NGP clinical studies. New isolated or cultivable microorganisms from healthy gut microbiota specifically related to obesogens' neutralization effects might be used as an NGP single strain or in consortia, both presenting functions and the ability to palliate metabolic-related disorders. Identification of holistic approaches for searching and using potential NGP, key aspects, the bias, gaps, and proposals of solutions are also considered in this review.
\end{abstract}

Keywords: next-generation probiotics; culturing; dietary obesogens exposure; obesity; endocrine pathogenesis; Endobolome

\section{Introduction \\ 1.1. Microbiota Gut Dysbiosis}

The microbiota is a microbial community that lives on and in the human body and it varies according to several factors such as age, diet, and lifestyle [1]. These microorganisms play a very important role in maintaining the health homeostasis or eubiosis [2]. It has been well-demonstrated that gastrointestinal tract (GIT) disorders are linked to microbiota alterations patterns (such as constipation, diarrhea, inflammatory bowel diseases $[3,4]$ ) that can be treated with probiotics. Moreover, important metabolic disorders, presenting altered levels of triacylglycerols, lipids, cholesterol, and fasting plasma glucose as clinical 
outcomes [5] are also linked to GIT dysbiosis. Similarly, fertility disorders such as polycystic ovary syndrome (PCOS) [6], gastrointestinal and reproductive cancers [7], or mental health disorders like depression, anorexia, or anxiety are also connected to microbiota dysbiosis [8].

\subsection{Traditional Probiotics vs. NGP in Obesity-Related Interventions and Treatments}

Probiotics, known as "live microorganisms, which, when administered in adequate amounts confer a health benefit on the host" by the Food and Agriculture Organization of the United Nations (FAO) and the World Health Organization (WHO) [9], have been empirically selected due to their extensive use in fermented foods for centuries and their safety history. Conversely, because of this broad definition, their use has become widespread, making them less effective against specific diseases [10]. Since then, numerous studies have been published in order to demonstrate the benefits of probiotics in an extensive list of disorders and/or diseases, traditional probiotics corresponding to strains or species generally within Lactobacillus and Bifidobacterium genera, and a few from other genera [11]. Traditional probiotics for clinical interventions in obesity-related disorders have been largely used, with huge differential impact on the clinical parameters and outcomes, depending on the basis of the individual microbiota (Table 1).

Additionally, it is well-known that the functional and specific positive biological effects of probiotics are strain-dependent. Therefore, validated clinical studies should define well the specific strains administered to the subjects as shown in Table $1[12,13]$.

However, new advances in high-throughput and -omics technologies allowed scientific community to characterize and identify new microorganisms called next generation probiotics (NGP) according to the beneficial basic definition of a probiotic, but they are better characterized by targeting specific diseases and clinical outcomes. NGPs have been initially well-designed and tested for obesity-related disorders (Table 2). Moreover, according to O'Toole et al. [14], there are substantial differences in the way of investigating traditional probiotics vs. NGP, driven by the high-throughput current technologies available and cumulated data evidence. Traditional probiotics harbor a limited number of microbial genera and species and they were initially selected according to their long history of safe use. Also, these probiotics tend to be searched and marketed by companies targeting general, narrowly defined populations. While NGPs belong to a wide range of genera and species, they are investigated by multidisciplinary approaches with microbiome and clinical expertise, the main goal of which is to obtain effective biosources to palliate specific microbiota dysbiosis and associated phenotypic disorders.

Table 1. Traditional probiotics for obesity-related interventional clinical trials and preclinical studies.

\begin{tabular}{llr}
\hline Lactobacillus Strains [15] & Study Design, Target Species & Reference Study \\
\hline L. bulgaricus Nutricion Medica ${ }^{\circledR}$ & ICT-Human & {$[16]$} \\
L. casei Shirota & ICT-Human & {$[17]$} \\
L. gasseri BNR17 & ICT-Human & {$[18]$} \\
L. reuteri V3401 & ICT-Human & {$[19]$} \\
L. rhamnosus CGMCC1.3724 & ICT-Human & {$[20]$} \\
L. acidophilus NS1 & PCS-Mice & {$[21]$} \\
L. johnsonii JNU3402 & PCS-Mice & {$[22]$} \\
L. plantarum Ln4 & PCS-Mice & {$[23]$} \\
L. curvatus HY7601 & PCS-Mice & {$[24]$} \\
L. fermentum CQPC07 & PCS-Mice & {$[25]$} \\
Bifidobacterium strains & Study design, Target Species, \\
B. animalis subsp. lactis 420 & ICT-Human & Reference study \\
B. breve B-3 & ICT-Human & {$[26]$} \\
B. infantis DSM24737 (VSL\#3) & ICT-Human & {$[27]$} \\
B. lactis HN019 & ICT-Human & {$[28]$} \\
B. longum APC1472 & ICT-Human/PCS-Mice & {$[29]$} \\
B. adolescentis & PCS-Mice & {$[30]$} \\
\hline
\end{tabular}


Table 1. Cont.

\begin{tabular}{llc}
\hline Lactobacillus Strains [15] & Study Design, Target Species & Reference Study \\
\hline B. bifidum BGN4 & PCS-Mice & [32] \\
Bacillus, Enterococcus, Streptococcus strains & Study design, Target Species, & Reference study \\
Bacillus coagulans Unique IS2 & ICT-Human & {$[33]$} \\
Bacillus amyloliquefaciens SC06 & PCS-Mice & {$[35]$} \\
Bacillus spp. & PCS-Mice & {$[36]$} \\
Enterococcus faecium R0026 & PCS-Mice & {$[37]$} \\
Enterococcus faecalis AG5 & PCS-Rats & {$[38]$} \\
Streptococcus thermophiles MN-ZLW-002 & PCS-Mice & Reference study \\
Saccharomyces strains & Study design, Target Species, & {$[39]$} \\
S. boulardii Biocodex & PCS-Mice & {$[40]$} \\
S. cerevisiae SFBE & PCS-Rats & \\
\hline
\end{tabular}

Traditional probiotics strains with obesity and anti-obesity effects. ICT: interventional clinical trials; PCS: preclinical studies.

Table 2. Next-generation probiotic strains used in obesity-related clinical trials and preclinical studies.

\begin{tabular}{|c|c|c|c|}
\hline $\begin{array}{c}\text { NGP Microbial Strains, } \\
\text { Target Species, } \\
\text { Study Reference }\end{array}$ & Study Design & Dietary Aspects & $\begin{array}{l}\text { Clinical Effects and } \\
\text { Functionality }\end{array}$ \\
\hline $\begin{array}{l}\text { Akkermansia muciniphila Muc } \\
\text { [CIP 107961]-Human [41] } \\
\text { [ClinicalTrials.gov Identifier: } \\
\text { NCT02637115] }\end{array}$ & $\begin{array}{l}\text { ICT: randomized, } \\
\text { double-blind, } \\
\text { placebo-controlled pilot study } \\
\text { Live probiotics } 10^{10} \text { / day vs. } \\
\text { pasteurized probiotics } \\
10^{10} \text { / day vs. placebo in } \\
\text { patients with metabolic } \\
\text { syndrome }\end{array}$ & $\begin{array}{l}\text { Normal dietary intake and } \\
\text { physical activity during the } \\
\text { study period }\end{array}$ & $\begin{array}{l}\uparrow \text { Insulin sensitivity, } \downarrow \\
\text { insulinemia and } \downarrow \text { plasma total } \\
\text { cholesterol }\end{array}$ \\
\hline $\begin{array}{l}\text { Akkermansia muciniphila } \\
\text { WST01-Human [42] } \\
\text { [ClinicalTrials.gov Identifier: } \\
\text { NCT04797442] }\end{array}$ & $\begin{array}{l}\text { ICT: randomized, } \\
\text { double-blind, } \\
\text { placebo-controlled, } \\
\text { multicenter clinical trial } \\
\text { Probiotics vs. placebo in } \\
\text { overweight or obese patients } \\
\text { with type } 2 \text { diabetes }\end{array}$ & $\begin{array}{l}\text { Intervention added onto } \\
\text { lifestyle }\end{array}$ & $\begin{array}{l}\text { Results will be available in } \\
\text { June } 2022\end{array}$ \\
\hline $\begin{array}{l}\text { Christensenella minuta } \\
\text { Xla1-Human [43] } \\
\text { [ClinicalTrials.gov Identifier: } \\
\text { NCT04663139] }\end{array}$ & $\begin{array}{l}\text { ICT: randomized, partially } \\
\text { placebo-controlled } \\
\text { double-blind } \\
\text { Probiotics vs. placebo in } \\
\text { healthy volunteers, } \\
\text { overweight, and obese adults }\end{array}$ & $\begin{array}{l}\text { Agreement to keep food, } \\
\text { drink, physical activities, and } \\
\text { alcohol consumption habits } \\
\text { unchanged throughout the } \\
\text { study }\end{array}$ & $\begin{array}{l}\text { Results will be available in } \\
\text { October } 2021\end{array}$ \\
\hline $\begin{array}{l}\text { Eubacterium } \\
\text { hallii_Human [44] } \\
\text { [ClinicalTrials.gov Identifier: } \\
\text { NCT04529473] }\end{array}$ & $\begin{array}{l}\text { ICT:double-blind, } \\
\text { randomized, } \\
\text { placebo-controlled } \\
\text { Probiotics vs. placebo }\end{array}$ & $\begin{array}{l}\text { Maintenance of dietary habits } \\
\text { and physical activity levels } \\
\text { throughout the study period }\end{array}$ & $\begin{array}{l}\text { Results will be available on } \\
\text { January } 2022\end{array}$ \\
\hline $\begin{array}{l}\text { Hafnia alvei } \\
\text { HA4597-Human [45] } \\
\text { [ClinicalTrials.gov Identifier: } \\
\text { NCT03657186] }\end{array}$ & $\begin{array}{l}\text { ICT: multicenter, randomized, } \\
\text { double-blind } \\
\text { placebo-controlled study. } \\
\text { Probiotics vs. placebo on } \\
\text { weight reduction in } \\
\text { overweight subjects }\end{array}$ & $\begin{array}{l}-20 \% \text { hypocaloric diet and } \\
\text { maintainance of the usual } \\
\text { physical activity }\end{array}$ & $\begin{array}{l}\uparrow \text { Weight loss in overweight } \\
\text { subjects, } \uparrow \text { feeling of fullness, } \\
\uparrow \text { loss of hip circumference, } \downarrow \\
\text { fasting glycemia }\end{array}$ \\
\hline $\begin{array}{l}\text { Lactococcus lactis } \\
\text { NRRL-B50571-Human [46] } \\
\text { [ClinicalTrials.gov Identifier: } \\
\text { NCT02670811] }\end{array}$ & $\begin{array}{l}\text { ICT: double-blind randomized } \\
\text { controlled } \\
\text { Probiotics vs. placebo on } \\
\text { prehypertensive subjects }\end{array}$ & $\begin{array}{l}\text { Participants were asked not to } \\
\text { change their diet or lifestyle } \\
\text { during the intervention }\end{array}$ & $\begin{array}{l}\downarrow \text { Systolic and diastolic blood } \\
\text { pressure, } \\
\downarrow \text { Triglyceride, total } \\
\text { cholesterol, and low-density } \\
\text { lipoprotein }\end{array}$ \\
\hline
\end{tabular}


Table 2. Cont.

\begin{tabular}{|c|c|c|c|}
\hline $\begin{array}{c}\text { NGP Microbial Strains, } \\
\text { Target Species, } \\
\text { Study Reference }\end{array}$ & Study Design & Dietary Aspects & $\begin{array}{l}\text { Clinical Effects and } \\
\text { Functionality }\end{array}$ \\
\hline $\begin{array}{l}\text { Escherichia coli Nissle } \\
\text { 1917_-Human [47] } \\
\text { [ClinicalTrials.gov Identifier: } \\
\text { NCT02144948] }\end{array}$ & $\begin{array}{l}\text { ICT: single group assignment. } \\
\text { Patients with type } 2 \text { diabetes }\end{array}$ & - & $\begin{array}{l}\text { Results not yet available or } \\
\text { posted on ClinicalTrials.gov } \\
\text { November } 2021\end{array}$ \\
\hline
\end{tabular}

Akkermansia muciniphila-Muc PCS: probiotics vs. control. [CIP 107961]—Mice [48,49] Obesity

High-fat diet/standard diet

$\downarrow$ Fat-mass gain, $\uparrow$ insulin sensitivity, restore gut barrier function by acting on TLR2, $\uparrow$ mucus later thickness; similar effects by a purified membrane protein alone (Amuc_1100)

$\downarrow$ Lipid accumulation in liver and serum, $\downarrow$ insulin levels, $\uparrow$

Clostridium butyricum CGMCC0313.1-Mice [50] PCS: probiotics vs. control. Obesity

High-fat diet/standard diet

High-fat diet/standard diet

Faecalibacterium prausnitzii VPI PCS: probiotics vs. control. C13-20-A-Mice [51] Obesity

PCS: probiotics vs. control. Obesity

High-fat diet/standard diet

Bacteroides uniformis CECT 7771- Mice [52]

glucose tolerance, $\uparrow$ insulin sensitivity, $\downarrow$ TNF- $\alpha$ and $\uparrow$ IL-10 and IL-22 in colon

$\uparrow$ Hepatic health, $\downarrow$ adipose tissue inflammation

$\downarrow$ Weight gain; $\downarrow$ dietary fat absorption; $\downarrow$ liver steatosis; $\downarrow$ serum cholesterol, triglyceride, glucose, insulin and leptin; $\uparrow$ glucose tolerance; $\uparrow$ TNF- $\alpha$ by DCs after LPS stimulation; $\uparrow$ phagocytosis

$\downarrow$ Obesity by $\uparrow$ adipose tissue $\begin{array}{lll}\text { Parabacteroides goldsteinii JCM } & \text { PCS: probiotics vs. control. } & \text { High-fat diet/standard diet } \\ \text { 13446-Mice [53] } & \text { Obesity }\end{array}$ thermogenesis, $\uparrow$ intestinal integrity $\downarrow$ inflammation, $\uparrow$ insulin sensitivity

$\begin{array}{ll}\text { Christensenella } & \text { PCS: probiotics vs. control. } \\ \text { minuta-Mice [54] } & \text { Obesity }\end{array}$

$\downarrow$ Weight gain, $\downarrow$ adiposity. Highly heritable in a lean host phenotype

$\uparrow$ Energy metabolism and $\uparrow$ Eubacterium hallii DSM PCS: probiotics vs. control. 17630-Mice [55] Diabetes

High-fat diet/standard diet insulin sensitivity through glycerol conversion 3hydroxypropionaldehyde

$\uparrow$ Beneficial anti-obesity and metabolic effects, $\downarrow$ food intake, $\downarrow$ body weight and $\downarrow$ fat mass gain

\begin{tabular}{|c|c|c|}
\hline $\begin{array}{l}\text { Hafnia alvei } \\
\text { HA4597-Mice [56] }\end{array}$ & $\begin{array}{l}\text { PCS: probiotics vs. control. } \\
\text { Obesity }\end{array}$ & High-fat diet/standard diet \\
\hline
\end{tabular}

Lactococcus lactis (GMM)
LL-pCYT: HSP65-6P277 and
LL-pHJ-Mice [57]

Escherichia coli Nissle 1917

(EcN-GMM)- Mice [58]

PCS: probiotics vs. control. Obesity

PCS: probiotics vs. control. Obesity
High-fat diet/standard diet

$\downarrow$ Antigen-specific of cellular immunity

Modulation of the neuropeptide expression of energy intake and expenditure in the hypothalamus

NGP tested with anti-obesity effects; DC: dendritic cells; IL: interleukin; ICT: interventional clinical trials; LPS: lipopolysaccharide; PCS: preclinical studies; TLR2: toll-like receptor 2; TNF: tumor necrosis factor. 


\section{Information and Criteria for Searching and Culturing Next-Generation Probiotics}

The search for NGP that are able to modulate the effects of obesogenic and microbiota disruptor chemicals will request the following information according to the corresponding stepwise criteria (Figure 1).

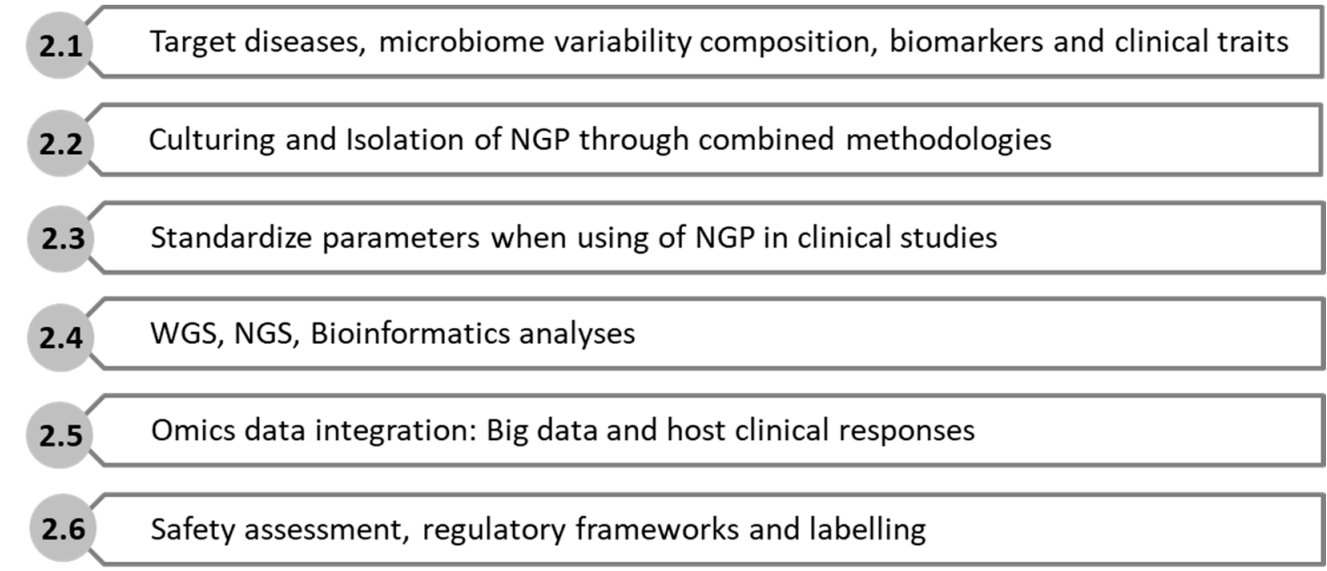

Figure 1. Next Generation Probiotics (NGP) criteria to be applied for searching strategies, Whole Genome Sequencign (WGS), Next Generation Sequencing (NGS):

\subsection{Target Diseases, Microbiome Variability Composition, Biomarkers and Clinical Traits}

2.1.1. Obesity, Metabolic, and Endocrine Diseases: Variability of Microbiota Composition

Interestingly, multiple convergent clinical studies have found differences between the microbiota of obese and healthy patients [59]. The clearest biomarker related to obesity appears to be Firmicutes-to-Bacteroidetes ratio. A higher ratio has been observed in obese or metabolic syndrome populations compared to the healthy ones [60,61]. Specific taxa seem to contribute to this ratio in obese patients: the genera Staphylococcus $[62,63]$ and Clostridium [64], inside the Firmicutes phylum, have been shown to have a positive association with obesity. Moreover, an increase in butyrate and acetate synthesis may contribute to an increase in energy harvest in obese people, and many butyrate-producing species belong to the Firmicutes phylum [65].

The main variations of microbiota taxa found in patients suffering from obesity, diabetes, metabolic syndrome, liver diseases, and endocrine-related disorders are summarized in Table 3. The present work focused on those species or taxa whose abundance was comparatively different between patients and healthy individuals. Therefore, isolating and culturing these microbial species would allow us to test and verify their biological functions, and if the effects were clinically proved, they could be proposed as beneficial microbial or NGP.

Interestingly, levels of traditional probiotics from the genera Lactobacillus and Bifidobacterium seem to be higher in obesity- and endocrine-related diseases accordint to data retrieved and summarized in Table 3. Conversely, the species of NGP that are recognized and clinically tested, seem to be lower in obesity-related patients. Therefore, species tested from the genera Akkermansia, Faecalibacterium, Eubacterium, Bacteroides, Parabacteroides, and Christensenella could contribute to restore the microbial misbalances observed. In this sense, new beneficial microbes or NGP searching approaches might be successfully based on culturing and isolating those new genera and species that present a differential abundance between patients and healthy subjects and they can be linked to relevant clinical outcome. 
Table 3. Clinical trials and variations of the main microbiota taxa found in specimens from patients suffering metabolic- and endocrine-related diseases.

\begin{tabular}{|c|c|c|c|c|c|}
\hline Reference & $\begin{array}{l}\text { Subjects and } \\
\text { Disease }\end{array}$ & Dietary Aspects & $\begin{array}{l}\text { Sample Size and } \\
\text { Clinical Traits }\end{array}$ & Detection Technique & Microbial Taxa Modifications \\
\hline Zhong et al. [66] & $\begin{array}{l}\text { Human } \\
\text { Obesity }\end{array}$ & NA & $\begin{array}{l}N=382 ; \text { MHNO } n=191 \\
\text { MUNO } n=61 ; \text { MHO } \\
n=66 ; \text { MUO } n=64\end{array}$ & $\begin{array}{l}\text { MiSeq platform (Illumina) } \\
\text { V3-V4 region of the } 16 S \\
\text { rRNA gene }\end{array}$ & $\begin{array}{l}\uparrow \text { Lachnospiraceae, Bacteroidaceae, } \\
\text { Methanobacteriaceae and } \\
\text { Pasteurellaceae in MHNO and } \\
\text { MUNO }\end{array}$ \\
\hline Jonduo et al. [67] & $\begin{array}{l}\text { Human } \\
\text { Obesity }\end{array}$ & $\begin{array}{l}\text { Participant's } \\
\text { predominantly } \\
\text { plant-based diet: } \\
\text { vegetables (e.g., sweet } \\
\text { potato, cassava, plantain, } \\
\text { and beans) }\end{array}$ & $\begin{array}{l}n=18 ; \text { OB } n=9 ; \text { Non-OB } \\
n=9\end{array}$ & $\begin{array}{l}454 \text { GS FLX platform or } \\
454 \text { GS JUNIOR system } \\
\text { (Roche) } \\
\text { V1-V2 region of the } 16 S \\
\text { rRNA gene }\end{array}$ & $\begin{array}{l}\uparrow \text { Prevotella in almost all } \\
\text { individuals }\end{array}$ \\
\hline Thingholm et al. [68] & $\begin{array}{l}\text { Human } \\
\text { Obesity }\end{array}$ & NA & $\begin{array}{l}n=1280 ; \mathrm{LH} n=633 ; \mathrm{OBH} \\
n=494 ; \mathrm{OBT} 2 \mathrm{D} n=153\end{array}$ & $\begin{array}{l}\text { MiSeq platform (Illumina) } \\
\text { V1-V2 region of 16S rRNA } \\
\text { gene }\end{array}$ & $\begin{array}{l}\downarrow \text { Akkermansia, } \\
\text { Faecalibacterium, Oscillibacter, } \\
\text { and Alistipes in obese } \\
\text { individuals } \\
\downarrow \text { Faecalibacterium prausnitzii } \\
\text { in obese individuals }\end{array}$ \\
\hline Schwiertz et al. [65] & $\begin{array}{l}\text { Human } \\
\text { Obesity }\end{array}$ & Western diet & $\begin{array}{l}n=98 ; \mathrm{HC} n=30 ; \mathrm{OW} n= \\
35 ; \mathrm{OB} n=33\end{array}$ & qPCR & $\begin{array}{l}\uparrow \text { Bacteroides in overweight vs. } \\
\text { HC } \\
\downarrow \text { Ruminococcus flavefaciens in } \\
\text { overweight and obese } \\
\downarrow \text { Bifidobacterium and } \\
\text { Clostridium leptum in obese } \\
\downarrow \text { Methanobrevibacter in } \\
\text { overweight and obese }\end{array}$ \\
\hline Gao et al. [69] & $\begin{array}{l}\text { Human } \\
\text { Obesity }\end{array}$ & NA & $\begin{array}{l}n=192 ; \mathrm{HC} n=25 ; \mathrm{OW} n \\
=22 ; \mathrm{OB} n=145\end{array}$ & $\begin{array}{l}\text { MiSeq platform (Illumina) } \\
\text { V4 region of the } 16 \mathrm{~S} \text { rRNA } \\
\text { gene }\end{array}$ & $\begin{array}{l}\uparrow \text { Lachnoclostridium, Fusobacterium, } \\
\text { Escherichia-Shigella, Klebsiella, } \\
\text { Bacillus, and Pseudomonas in OW } \\
\text { and OB } \\
\uparrow \text { Clostridia, Faecalibacterium, } \\
\text { Ruminococcus, Bifidobacterium, and } \\
\text { Lachnospiraceae_UCG_008 in HC }\end{array}$ \\
\hline
\end{tabular}


Table 3. Cont

\begin{tabular}{|c|c|c|c|c|c|}
\hline Reference & $\begin{array}{l}\text { Subjects and } \\
\text { Disease }\end{array}$ & Dietary Aspects & $\begin{array}{l}\text { Sample Size and } \\
\text { Clinical Traits }\end{array}$ & Detection Technique & Microbial Taxa Modifications \\
\hline Armougom et al. [70] & $\begin{array}{l}\text { Human } \\
\text { Obesity } \\
\text { Anorexia nervosa }\end{array}$ & NA & $\begin{array}{l}n=49 ; \mathrm{HC} n=20 ; \mathrm{OB} n= \\
20 ; \mathrm{AN} n=9\end{array}$ & qPCR & $\uparrow$ Lactobacillus in $\mathrm{OB}$ \\
\hline Horie et al. [71] & $\begin{array}{l}\text { Mice } \\
\text { Type } 2 \text { diabetes }\end{array}$ & NA & $\begin{array}{l}\text { 5-week-old TSNO mice } \\
n=5 ; 5 \text {-week-old TSOD } \\
\text { mice } n=5 ; 12 \text {-week-old } \\
\text { TSNO mice } n=5 ; \\
\text { 12-week-old TSOD mice } \\
n=5\end{array}$ & qPCR & $\begin{array}{l}\uparrow \text { Lactobacillus in TSOD vs. TSNO } \\
\uparrow \text { Bacteroidales and Lachnospiraceae } \\
\text { in TSNO vs. TSOD } \\
\uparrow \text { Turicibacter and SMB53 in TSOD }\end{array}$ \\
\hline Larsen et al. [72] & $\begin{array}{l}\text { Human } \\
\text { Type } 2 \text { diabetes }\end{array}$ & NA & $\begin{array}{l}n=36 ; \mathrm{HC} n=18 ; \mathrm{T} 2 \mathrm{D} \\
n=18\end{array}$ & $\begin{array}{l}\text { MiSeq platform (Illumina) } \\
\text { V4 region of the 16S rRNA } \\
\text { gene }\end{array}$ & $\begin{array}{l}\uparrow \text { Firmicutes in } \mathrm{HC} \uparrow \\
\text { Bacteroidetes and } \\
\text { Betaproteobacteria in T2D } \\
\downarrow \text { Clostridia in T2D }\end{array}$ \\
\hline Sedighi et al. [73] & $\begin{array}{l}\text { Human } \\
\text { Type } 2 \text { diabetes }\end{array}$ & NA & $\begin{array}{l}n=36 ; \mathrm{HC} n=18 ; \mathrm{T} 2 \mathrm{D} \\
n=18\end{array}$ & qPCR & $\begin{array}{l}\uparrow \text { Lactobacillus in T2D } \\
\uparrow \text { Bifidobacterium in HC } \\
\uparrow \text { Fusobacterium in T2D }\end{array}$ \\
\hline Moghadam et al. [74] & $\begin{array}{l}\text { Human } \\
\text { Tipe } 2 \text { diabetes }\end{array}$ & NA & $\begin{array}{l}n=36 ; \mathrm{HC} n=18 ; \mathrm{T} 2 \mathrm{D} \\
n=18\end{array}$ & qPCR & $\begin{array}{l}\uparrow \text { Faecalibacterium prausnitzii in } \\
\mathrm{HC}\end{array}$ \\
\hline Ahmad et al. [75] & $\begin{array}{l}\text { Human } \\
\text { Type } 2 \text { diabetes } \\
\text { Obesity }\end{array}$ & $\begin{array}{l}\text { Eastern dietary habits } \\
\text { (high carbohydrate and } \\
\text { fat intake, low fiber } \\
\text { intake) }\end{array}$ & $\begin{array}{l}n=60 ; \mathrm{HC} n=20 \\
\text { Obese-T2D } n=40\end{array}$ & $\begin{array}{l}\text { MiSeq platform (Illumina) } \\
\text { V3-V4 region of the } 16 S \\
\text { rRNA gene }\end{array}$ & $\begin{array}{l}\uparrow \text { Firmicutes in Obese-T2D } \\
\uparrow \text { Clostridia, Negativicutes, } \\
\text { Coriobacteria, Acidobacteria, } \\
\text { Deferribacteres, and } \\
\text { Gemmatimonadetes in } \\
\text { obese-T2D } \\
\uparrow \text { Verrucomicrobia, Bacteroidetes, } \\
\text { Proteobacteria, and Elusimicrobia } \\
\text { in HC } \\
\uparrow \text { Prevotella P4_76, Clostridiales, } \\
\text { Porphyromonadaceae bacterium } \\
\text { DJF B175, Candidatus Alistipes } \\
\text { marseilloanorexic AP11, Bacillus } \\
\text { sporothermodurans, Staphylococcus } \\
\text { SV3, and Iamia in obese-T2D }\end{array}$ \\
\hline
\end{tabular}


Table 3. Cont

\begin{tabular}{|c|c|c|c|c|c|}
\hline Reference & $\begin{array}{l}\text { Subjects and } \\
\text { Disease }\end{array}$ & Dietary Aspects & $\begin{array}{l}\text { Sample Size and } \\
\text { Clinical Traits }\end{array}$ & Detection Technique & Microbial Taxa Modifications \\
\hline Ejtahed et al. [76] & $\begin{array}{l}\text { Human } \\
\text { Type } 2 \text { diabetes } \\
\text { Type } 1 \text { diabetes }\end{array}$ & NA & $\begin{array}{l}n=110 ; \mathrm{HC} n=40 ; \mathrm{T} 2 \mathrm{D} \\
n=49 ; \\
\text { T1D } n=21\end{array}$ & qPCR & $\begin{array}{l}\uparrow \text { Escherichia, Prevotella, and } \\
\text { Lactobacillus in T1D and T2D } \\
\uparrow \text { Bifidobacterium, Roseburia, and } \\
\text { Bacteroides in HC } \\
\downarrow \text { Faecalibacterium in T1D vs. } \\
\text { HC and T2D }\end{array}$ \\
\hline Takagi et al. [77] & $\begin{array}{l}\text { Human } \\
\text { Type } 2 \text { diabetes } \\
\text { Hypertension } \\
\text { Hyperlipidemia }\end{array}$ & NA & $\begin{array}{l}n=239 ; \mathrm{HC} n=54 ; \mathrm{HT} \\
n=97 ; \\
\text { HL } n=96 ; \mathrm{T} 2 \mathrm{D} n=162\end{array}$ & $\begin{array}{l}\text { MiSeq platform (Illumina) } \\
\text { V3-V4 region of the } 16 S \\
\text { rRNA gene }\end{array}$ & $\begin{array}{l}\uparrow \text { Actinobacteria in HT, HL, T2D, } \\
\text { RISK2, and RISK3 } \\
\downarrow \text { Bacteroidetes in HT, HL, T2D } \\
\text { and RISK3 } \\
\uparrow \text { Bifidobacterium in HL, T2D, } \\
\text { RISK1 and RISK2 } \\
\uparrow \text { Collinsella in HT, HL, T2D, } \\
\text { RISK2 and RISK3 } \\
\uparrow \text { Escherichia in RISK } 3 \\
\downarrow \text { Alistipes in HL }\end{array}$ \\
\hline Wang et al. [78] & $\begin{array}{l}\text { Human } \\
\text { Non-alcoholic fatty } \\
\text { liver disease }\end{array}$ & Omnivorous Chinese diet & $\begin{array}{l}n=126 ; \text { HC } n=83 \\
\text { NAFLD } n=43\end{array}$ & $\begin{array}{l}454 \text { Life Sciences Genome } \\
\text { Sequencer FLX system } \\
\text { (Roche) } \\
\text { V3 region of the } 16 S \text { rRNA } \\
\text { gene }\end{array}$ & $\begin{array}{l}\downarrow \text { Firmicutes } \uparrow \text { Bacteroidetes in } \\
\text { NAFLD } \\
\uparrow \text { Bacteroidia } \downarrow \text { Clostridia in } \\
\text { NAFLD } \\
\downarrow \text { Coprococcus, } \\
\text { Pseudobutyrivibrio, Moryella, } \\
\text { Roseburia, Anaerotruncus, } \\
\text { Ruminococcus, } \\
\text { Anaerosporobacter, } \\
\text { andLactobacillus in NAFLD }\end{array}$ \\
\hline Li et al. [79] & $\begin{array}{l}\text { Human } \\
\text { Non-alcoholic fatty } \\
\text { liver disease }\end{array}$ & $\begin{array}{l}\text { No dietary restrictions } \\
\text { imposed }\end{array}$ & $\begin{array}{l}n=67 ; \mathrm{HC} n=37 ; \text { NAFLD } \\
n=30\end{array}$ & $\begin{array}{l}\text { MiSeq platform (Illumina) } \\
\text { V4 region of the16S rRNA } \\
\text { gene }\end{array}$ & $\begin{array}{l}\uparrow \text { Lactobacillaceae, } \\
\text { Peptostreptococcaceae, } \\
\text { Veillonellaceae, EtOH8, } \\
\text { Coprobacillaceae, and } \\
\text { Erysipelotrichaceae in NAFLD } \\
\uparrow \text { Porphyromonas and Succinivibrio } \\
\text { in NAFLD } \\
\downarrow \text { Odoribacter and Proteus in } \\
\text { NAFLD }\end{array}$ \\
\hline
\end{tabular}


Table 3. Cont

\begin{tabular}{|c|c|c|c|c|c|}
\hline Reference & $\begin{array}{l}\text { Subjects and } \\
\text { Disease }\end{array}$ & Dietary Aspects & $\begin{array}{l}\text { Sample Size and } \\
\text { Clinical Traits }\end{array}$ & Detection Technique & Microbial Taxa Modifications \\
\hline Shen et al. [80] & $\begin{array}{l}\text { Human } \\
\text { Non-alcoholic fatty } \\
\text { liver disease }\end{array}$ & NA & $\begin{array}{l}n=47 ; \mathrm{HC} n=22 ; \text { NAFLD } \\
n=25\end{array}$ & $\begin{array}{l}454 \text { GS-FLX platform } \\
\text { (Roche) } \\
\text { V3-V5 region of the } \\
\text { 16S rRNA gene }\end{array}$ & $\begin{array}{l}\uparrow \text { Proteobacteria, Fusobacteria, } \\
\text { Lachnospiraceae_Incertae_Sedis } \\
\text { and Blautia in NAFLD } \\
\uparrow \text { Bacteroidetes and Prevotella in } \\
\text { HC } \\
\uparrow \text { Escherichia_Shigella, } \\
\text { Clostridium_XVIII, and } \\
\text { Staphylococcus in NAFLD }\end{array}$ \\
\hline Raman et al. [81] & $\begin{array}{l}\text { Human } \\
\text { Non-alcoholic fatty } \\
\text { liver disease }\end{array}$ & $\begin{array}{l}\text { No dietary restrictions } \\
\text { imposed }\end{array}$ & $\begin{array}{l}n=60 ; \mathrm{HC} n=30 ; \text { NAFLD } \\
n=30\end{array}$ & qPCR & $\begin{array}{l}\uparrow \text { Lactobacillus, Roseburia, Dorea, } \\
\text { and Robinsoniella in NAFLD } \\
\downarrow \text { Oscillibacterin NAFLD }\end{array}$ \\
\hline Michail et al. [82] & $\begin{array}{l}\text { Human } \\
\text { Non-alcoholic fatty } \\
\text { liver disease } \\
\text { Obesity }\end{array}$ & $\begin{array}{l}\text { No dietary restrictions } \\
\text { imposed }\end{array}$ & $\begin{array}{l}n=50 ; \operatorname{HC} n=26 ; \text { NAFLD } \\
n=13 ; \text { Obese } \\
\text { non-NAFLD } n=11\end{array}$ & qPCR & $\begin{array}{l}\uparrow \text { Gammaproteobacteria, Prevotella, } \\
\text { and Epsilonproteobacteria in } \\
\text { NAFLD } \\
\downarrow \text { Clostridia } \uparrow \text { Alphaproteobacteria } \\
\text { in obese non-NAFLD }\end{array}$ \\
\hline Nistal et al. [83] & $\begin{array}{l}\text { Human } \\
\text { Non-alcoholic fatty } \\
\text { liver disease } \\
\text { Obesity }\end{array}$ & NA & $\begin{array}{l}n=73 ; \operatorname{HC} n=20 ; \\
\text { Obese-NAFLD } n=36 ; \\
\text { Obese non-NAFLD } n=17\end{array}$ & $\begin{array}{l}\text { MiSeq platform (Illumina) } \\
\text { V3-V4 region of the } 16 S \\
\text { rRNA gene }\end{array}$ & $\begin{array}{l}\uparrow \text { Bacilli in obese-NAFLD } \\
\downarrow \text { Betaproteobacteria in } \\
\text { obese-NAFLD vs. obese } \\
\text { non-NAFLD } \\
\downarrow \text { Oscillospira, Akkermansia, } \\
\text { and Eubacterium in } \\
\text { obese-NAFLD and obese } \\
\text { non-NAFLD vs. HC } \\
\uparrow \text { Megasphaera, Lactobacillus, } \\
\text { Acidominococcus in obese-NAFLD, } \\
\text { and obese non-NAFLD vs. HC } \\
\downarrow \text { Blautia, Alkaliphilus, and } \\
\text { Flavobacterium in obese-NAFLD } \\
\uparrow \text { Staphylococcus in obese-NAFLD }\end{array}$ \\
\hline
\end{tabular}


Table 3. Cont

\begin{tabular}{|c|c|c|c|c|c|}
\hline Reference & $\begin{array}{l}\text { Subjects and } \\
\text { Disease }\end{array}$ & Dietary Aspects & $\begin{array}{l}\text { Sample Size and } \\
\text { Clinical Traits }\end{array}$ & Detection Technique & Microbial Taxa Modifications \\
\hline Loomba et al. [84] & $\begin{array}{l}\text { Human } \\
\text { Non-alcoholic fatty } \\
\text { liver disease } \\
\text { Fibrosis }\end{array}$ & NA & $\begin{array}{l}n=86 ; \text { NAFLD } n=72 \\
\text { Fibrosis } n=14\end{array}$ & qPCR & $\begin{array}{l}\uparrow \text { Firmicutes in NAFLD, } \uparrow \\
\text { Proteobacteria in fibrosis } \\
\uparrow \text { Eubacterium rectale and } \\
\text { Bacteroides vulgatus in NAFLD } \\
\uparrow \text { Bacteroides vulgatus and } \\
\text { Escherichia coli in fibrosis } \\
\downarrow \text { Ruminococcus obeum, and } \\
\text { Eubacterium rectale in fibrosis }\end{array}$ \\
\hline $\begin{array}{l}\text { Del Chierico et al. } \\
\text { [85] }\end{array}$ & $\begin{array}{l}\text { Human } \\
\text { Non-alcoholic fatty } \\
\text { liver disease } \\
\text { Non-alcoholic } \\
\text { steatohepatitis } \\
\text { Obesity }\end{array}$ & NA & $\begin{array}{l}n=115 ; \mathrm{HC} n=54, \mathrm{OB} \\
n=8 ; \\
\text { NAFLD } n=27 ; \mathrm{NASH} \\
n=26\end{array}$ & $\begin{array}{l}\text { 454- Junior Genome } \\
\text { Sequencer FLX system } \\
\text { (Roche) } \\
\text { V1-V3 region of the } 16 \mathrm{~S} \\
\text { rRNA gene }\end{array}$ & $\begin{array}{l}\uparrow \text { Bradyrhizobium, Anaerococcus, } \\
\text { Peptoniphilus, Propionibacterium } \\
\text { acnes, Dorea, and Ruminococcus } \\
\downarrow \text { Oscillospira and Rikenellaceae } \\
\text { in NAFLD } \\
\uparrow \text { Ruminococcus, Dorea, and } \\
\text { Blautia in NASH }\end{array}$ \\
\hline Da Silva et al. [86] & $\begin{array}{l}\text { Human } \\
\text { Non-alcoholic } \\
\text { steatohepatitis } \\
\text { Simple steatosis }\end{array}$ & 7-day food record & $\begin{array}{l}n=67 ; \mathrm{HC} n=28 ; \mathrm{SS} \\
n=15: \mathrm{NASH} n=24\end{array}$ & MiSeq platform (Illumina) & $\begin{array}{l}\downarrow \text { Ruminococcus, } \\
\text { Faecalibacteriumprausnitzii, } \\
\text { and Coprococcus in NASH and } \\
\text { SS vs. HC }\end{array}$ \\
\hline Mouzaki et al. [87] & $\begin{array}{l}\text { Human } \\
\text { Non-alcoholic } \\
\text { steatohepatitis } \\
\text { Simple steatosis }\end{array}$ & $\begin{array}{l}\text { HC patients were } \\
\text { consuming more calories } \\
\text { per kg compared to } \\
\text { patients with NASH }\end{array}$ & $\begin{array}{l}n=50 ; \mathrm{HC} n=17 ; \mathrm{SS} \\
n=11 ; \mathrm{NASH} n=22\end{array}$ & $\mathrm{qPCR}$ & $\begin{array}{l}\downarrow \text { Bacteroidetes in NASH vs. SS } \\
\text { and HC } \\
\uparrow \text { Clostridium coccoides in NASH } \\
\text { vs. SS }\end{array}$ \\
\hline Zhu et al. [88] & $\begin{array}{l}\text { Human } \\
\text { Non-alcoholic } \\
\text { steatohepatitis } \\
\text { Obesity }\end{array}$ & NA & $\begin{array}{l}n=63 ; \mathrm{HC} n=16 ; \mathrm{OB} \\
n=25 ; \mathrm{NASH} n=22\end{array}$ & qPCR & $\begin{array}{l}\uparrow \text { Bacteroides } \downarrow \text { Firmicutes in } \\
\text { NASH and OB } \\
\downarrow \text { Blautia and Faecalibacterium } \\
\text { in NASH and OB }\end{array}$ \\
\hline
\end{tabular}


Table 3. Cont.

\begin{tabular}{|c|c|c|c|c|c|}
\hline Reference & $\begin{array}{l}\text { Subjects and } \\
\text { Disease }\end{array}$ & Dietary Aspects & $\begin{array}{l}\text { Sample Size and } \\
\text { Clinical Traits }\end{array}$ & Detection Technique & Microbial Taxa Modifications \\
\hline Boursier et al. [89] & $\begin{array}{l}\text { Human } \\
\text { Non-alcoholic } \\
\text { steatohepatitis } \\
\text { Fibrosis }\end{array}$ & NA & $\begin{array}{l}n=57 ; \text { Non-NASH } n=20 \\
\text { NASH } n=10 ; \text { Fibrosis } \geq 2 \\
n=27\end{array}$ & $\begin{array}{l}\text { Illumina } \\
\text { V4 region of 16S rRNA } \\
\text { gene }\end{array}$ & $\begin{array}{l}\uparrow \text { Bacteroides } \downarrow \text { Prevotella in } \\
\mathrm{NASH} \\
\uparrow \text { Bacteroides and Ruminococcus in } \\
\text { fibrosis } \geq 2 \\
\downarrow \text { Prevotella in fibrosis } \geq 2\end{array}$ \\
\hline Qin et al. [90] & $\begin{array}{l}\text { Human } \\
\text { Cirrhosis }\end{array}$ & NA & $\begin{array}{l}n=179 ; \text { HC } n=83 \\
\text { Cirrhosis } n=96\end{array}$ & qPCR & $\begin{array}{l}\uparrow \text { Streptococcus, Veillonella, } \\
\text { Clostridium and Prevotella in } \\
\text { cirrhosis } \\
\uparrow \text { Eubacterium and Alistipes in HC } \\
\downarrow \text { Bacteroides in cirrhosis }\end{array}$ \\
\hline Lim et al. [91] & $\begin{array}{l}\text { Human } \\
\text { Methabolic } \\
\text { syndrome }\end{array}$ & NA & $\begin{array}{l}n=655 ; \text { Monozygotic } \\
\text { twins } n=306 ; \text { Dizygotic } \\
\text { twins } n=74 ; \text { Siblings } \\
n=275\end{array}$ & $\begin{array}{l}\text { MiSeq platform (Illumina) } \\
\text { V4 region of the } 16 \mathrm{~S} \\
\text { rRNA gene }\end{array}$ & $\begin{array}{l}\uparrow \text { Lactobacillus, Sutterella and } \\
\text { Methanobrevibacter in MetS } \\
\downarrow \text { Parabacteroides, } \\
\text { Bifidobacterium, Odoribacter, } \\
\text { Akkermansia } \text { and } \\
\text { Christensenella in MetS }\end{array}$ \\
\hline
\end{tabular}

Genera and species in bold letters highlight the decreased microorganisms to be considered as potential NGP to be searched, cultured and assayed for their anti-obesity modulation effects. AN: anorexia nervosa; HC: healthy control; HL: hyperlipidemia; HT: hypertension; LH: lean healthy; MetS: metabolic syndrome; MHNO: metabolically healthy non-obese; MHO: metabolically healthy obese; MUNO: metabolically unhealthy non-obese; MUO: metabolically unhealthy obese; NA: Not applicable; NAFLD: non-alcoholic fatty liver disease;

NASH: non-alcoholic steatohepatitis; OB: obese; OBH: obese healthy; OBT2D: obese type 2 diabetes; OW: overweight; RISK1: patients with only one disease; RISK2: patients with two diseases; RISK3: patients with three diseases; SS: simple steatosis; T1D: type 1 diabetes; T2D: type 2 diabetes; TSNO: Tsumura Suzuki Obese Diabetes mice; TSOD: Tsumura Suzuki, Non-Obesity mice. 


\subsubsection{Nutrition and Diets, Dietary Exposure to Obesogens, and Microbiome Interactions}

Dietary intake is considered one of the determining factors that modulate the microbial composition and diversity of the gut microbiome, which could promote either beneficial or negative effects on host health and physiological functions [92,93]. A Western-style diet, rich in animal-based foods, can increase the patient's levels of bile-tolerant bacteria, including Bacteroidetes (e.g., Bacteroides and Alistipes), and Proteobacteria (Bilophila), and decrease levels of fiber-degrading bacteria such as Firmicutes (e.g., Eubacterium and $R u$ minococccus) [94]. Conversely, the Mediterranean diet and plant-based diets can promote fiber-degrading bacteria, mainly including genera of the Firmicutes phylum, together with increased overall diversity of the gut microbiota [95]. There are fewer studies about the associations between dietary habits and the gut microbiota in the Asiatic populations $[96,97]$, which are characterized by higher intakes of several fermented foods containing microorganisms similar to probiotic strains [98,99], which could affect the composition and diversity of the gut microbiota, thus affecting human health [100].

In addition, globalized population has incorporated much more processed foods and artificial products into their diets to keep up with the rapid pace of lifestyles. Therefore, the exposure to dietary contaminants became a cause of health concern worldwide [101-103]. Processed foods could contain obesogens derived from endocrine-disrupting chemicals that have also an effect on the gut microbiota, promoting adipogenesis and weight gain, as well as microbiome dysbiosis [104,105], which is linked to multiple diseases and adverse health outcomes $[106,107]$. The enzymatic arsenal of gut microbiota plays a key role in metabolizing dietary obesogens from processed or cooked food, promoting different outcomes: (i) Gut microbiota could protect against the carcinogenic and genotoxic substances by degrading or biotransforming them to less toxic compounds or facilitating their excretion [108,109]. (ii) Gut microbiota may also detoxify xenobiotics, for example, into genotoxins, or may reverse the detoxification implied by the host metabolism [110]. (iii) Gut microbiota is capable of transforming xenobiotics into less toxic and mutagenic substances, thus it may be able to lessen the chances of cancer and other dysbiosis effects [111]. (iv) Gut microbiome (human/animals) might be negatively affected by several food/feed additives (sweeteners, emulsifiers, preservatives, etc.) and other contaminants (BPA, Parabens, Pesticides, etc.) through triggering microbiota dysbiosis. Consequently, advances in toxicomicrobiomics are needed to study these complex and mutual influences between the ever-changing microbiome and obesogens of various origins, with emphasis on their fate and toxicity, and xenobiotic-modifying enzymes [112].

\subsection{Culturing and Isolation of NGP through Combined Methodologies}

The search for microbiological differences between the study groups (such as the healthy and the dysbiotic taxa groups) allows us to identify potential probiotics, and even detoxifying microorganisms, which could be used as NGP. However, this is followed by isolation and characterization of potential probiotics, and so far, none of the bacteria in the microbiota can be cultured in vitro yet [113]. This could be due to the difficulties of replicating essential aspects of their anaerobic environment [114] or the need to coculture with other bacteria from the same environment [115]. However, new media and modified procedures, such as improved culturomics, are continuously developing and evolving. They consist of multiple culture conditions with rapid identification of bacteria, raising the level of cultured bacteria and their possible use as bioresources or even NGP [116]. Table 4 summarizes the main putative new species isolated from recent culturing approaches in connection with the highlighted species underrepresented in obesity, which could be restored by a supplemented formula. Moreover, the isolation of strains from human microbiota able to biodegrade xenobiotics is successful through a directed cultivation approach with enriched media containing the specific xenobiotic [117]. BPA-tolerant strains were isolated in 30\% of infant fecal microbial culture libraries analyzed. Most isolated strains were phylogenetically related to the operational taxonomic group Bacillus amyloliquefaciens. The culture media most used for cultivation of specific gut microbial strains with success were yeast- 
extract-casein hydrolysate-fatty acids (YCFA); gifu anaerobic medium (GAM); brain-heart infusion (BHI); eosin methylene blue (EMB); Lactobacillus selection (LBS); gut microbiota medium (GMM); and Man, Rogosa, and Sharpe (MRS).

Table 4. Culturing approaches to favor specific microbiota species and NGP taxa and candidatus species.

\begin{tabular}{|c|c|c|c|}
\hline Reference/Sample & $\begin{array}{l}\text { Culture } \\
\text { Media }\end{array}$ & $\begin{array}{l}\text { Culture Media } \\
\text { Modifications }\end{array}$ & $\begin{array}{l}\text { Selected Favored Cultured } \\
\text { Microorganisms }\end{array}$ \\
\hline \multirow[t]{2}{*}{$\begin{array}{l}\text { Browne et al. [118] } \\
\text { Human }\end{array}$} & YCFA & $\begin{array}{l}\text { Glucose }(0.2 \%), \text { maltose } \\
(0.2 \%) \text {, and cellobiose } \\
(0.2 \%)\end{array}$ & $\begin{array}{l}\text { Aero-intolerant genus and } \\
\text { species }\end{array}$ \\
\hline & YCFA & $\begin{array}{l}\text { Pre-treatment with } \\
\text { ethanol } 70 \%(v / v), \text { glucose } \\
(0.2 \%) \text {, maltose }(0.2 \%) \text {, } \\
\text { cellobiose }(0.2 \%) \text {, sodium } \\
\text { taurocholate }(0.1 \%) \text {. } \\
\text { Spore-forming gut } \\
\text { aero-intolerant bacteria }\end{array}$ & $\begin{array}{l}\text { Alistipes finegoldii } \\
\text { Anaerotruncus colihominis } \\
\text { Blautia hydrogenotrophica; B. } \\
\text { obeum; B. wexlerae } \\
\text { Clostridum baratti; C. bartlettii; C. } \\
\text { clostridioforme; C. disporicum; C. } \\
\text { hathewayi; C.innocuum; C. } \\
\text { paraputrificum; C.perfringens } \\
\text { Coprococcus comes; C. eutactus } \\
\text { Prevotella copri } \\
\text { Roseburia hominis; R. intestinalis; } \\
\text { R. inulinvorans; } \\
\text { Ruminococcus bromii; R. gnavus; } \\
\text { R. obeum; R. torques }\end{array}$ \\
\hline $\begin{array}{l}\text { Chang et al. [119] } \\
\text { Human }\end{array}$ & YCFA & $\begin{array}{l}\text { Pre-incubation in blood } \\
\text { culture bottles } \\
\text { supplemented with 10\% } \\
\text { sheep blood and } 10 \% \\
\text { rumen }\end{array}$ & $\begin{array}{l}\text { Aero-intolerant bacteria } \\
\text { Alistipes shahii; A. onderdonkii, } \\
\text { Clostridium bifermentans, C. } \\
\text { innocuum, C. hiranonis, C. } \\
\text { butiricum, C. hathewayi, } \\
\text { C. bolteae, C. sporogenes, } \\
\text { Odoribacter splanchnicus }\end{array}$ \\
\hline
\end{tabular}

Aero-intolerant bacteria
Gotoh et al.

Microbial bank
[120] GAM NA
$72 \%$ of species of the top 56 species listed in the "human gut microbial gene catalogue" cultured in GAM
Outcome and Observations:

New Species Cultured: Potential NGP

68 new isolated species: 16S RNA similarity 86-97\%

Anaerotruncus colihominis

Blautia luti; B. hydrogenotrophica Clostridium boltae; C. celerecrescens; C. celerescens; C. clostridioforme; $\mathrm{C}$. cocleatum; C. disporicum; C. ghonii; C. hathewayi; C. innocuum; C. lituseburense; C. methylpentosum; C. nexile; C. oroticum; C. saccharogumia; C. saccharolyticum; C. thermocellum; C. xylanolyticum Coprococcus eutactus

Oscillibacter valericigenes

Roseburia faecis; $R$. inulinivorans

Ruminococcus albus; R.bromii; $R$.

flavefaciens; R. gnavus; R.obeum; $R$. torques

$22 \%$ of species isolated increase:

16S RNA similarity $93-97 \%$

3 new species isolated:

Longicatena caemuris

Bacillus alcalophilus

Pseudogracilibacillus auburnensis

Isolated species in GAM:

Anaerotruncus colihominis,

Blautia hansenii,

Clostridium nexile, C. asparagiforme, C. scindens,

Coprococcus comes

Roseburia intestinalis

Ruminococcus torques, $R$. lactaris, $R$. obeum, R. gnavus.

\begin{tabular}{|c|c|c|c|c|}
\hline $\begin{array}{l}\text { Lagier et al. } \\
\text { [121] } \\
\text { 16-years-old male }\end{array}$ & BHI & $\begin{array}{l}\text { Preincubation of the stool } \\
\text { with lytic E. coli } \mathrm{T} 1 \text { and } \mathrm{T} 4 \\
\text { phages }\end{array}$ & $\begin{array}{l}\text { Non-fastidious aerobic and } \\
\text { facultatively anaerobic bacteria }\end{array}$ & Enterobacter massiliensis strain JC163T \\
\hline \multirow{3}{*}{$\begin{array}{l}\text { Bailey and Coe [122] } \\
\text { Rhesus Monkeys }\end{array}$} & BHI & NA & $\begin{array}{l}\text { Non-fastidious aerobic and } \\
\text { facultatively anaerobic bacteria }\end{array}$ & NA \\
\hline & EMB & NA & $\begin{array}{l}\text { Gram-negative aerobic and } \\
\text { facultatively anaerobic bacteria }\end{array}$ & NA \\
\hline & LBS & NA & Aerobic members of lactobacilli & Lactobacillus spp. \\
\hline $\begin{array}{l}\text { Lei et al. [123] } \\
\text { Female mice }\end{array}$ & GMM & NA & Gut aero-intolerant bacteria & \\
\hline López-Moreno [117] & BHI & $\begin{array}{l}\text { Supplemented with } \\
\text { Obesogens: BPA, BPS }\end{array}$ & Anaerobic facultative Firmicutes & $\begin{array}{l}\text { Staphylococcus, Bacillus } \\
\text { amyloliquefaciens group, Streptococcus } \\
\text { salivarius }\end{array}$ \\
\hline López-Moreno [117] & MRS & $\begin{array}{l}\text { Supplemented with } \\
\text { Obesogens: BPA, BPS }\end{array}$ & Lactobacillus, Enterobacteria & $\begin{array}{l}\text { Latilactobacillus sakei, Enterococcus } \\
\text { faecium }\end{array}$ \\
\hline
\end{tabular}

YCFA: yeast-extract-casein hydrolysate-fatty acids; GAM: gifu anaerobic medium; BHI: brain-heart infusion; EMB: eosin methylene blue; LBS: Lactobacillus selection; GMM: gut microbiota medium; MRS; Man, Rogosa and Sharpe; BPA: Bisphenol A; BPS: Bisphenol S. Genera and species in bold letters highlight the microorganisms to be considered as potential NGP to be searched, cultured and assayed for their anti-obesity modulation effects. 


\subsection{Standardize Parameters When Using NGP in Clinical Studies}

Traditional probiotics (Table 1) were not regulated as drugs but instead as dietary supplements; they are not subjected to the same rigorous standards and could have quality control issues [124]. As previously described, numerous studies have been carried out to prove the benefits of probiotics in a large number of dysbioses, but without standardized steps on dosages, patterns of administration, and detailed strains.

There is no consensus on the minimum number of microorganisms that should be ingested to obtain a beneficial effect [125]. Since the effective dose of probiotics is influenced by multiple variables, it is difficult to standardize an optical dose [126]. Additionally, there is a need to investigate potential synergistic effects or antagonistic activity between strains in multi-strain vs. single-strain products [127]. Furthermore, it is well- demonstrated that the positive biological effects that the probiotics exert are strain-dependent, so it is necessary to obtain a taxonomic characterization to the strain level $[12,13]$. In previous reviews [128,129], we have seen an unharmonized broad range of intervention, total dose, and administration patterns of probiotics in obesity and fertility disorders. Finally, another parameter to be harmonized is the target population, since it has been seen that the beneficial effect of a probiotic in a population may not be adequate for another population, even causing potential adverse effects [130].

\subsection{Whole Genome Sequencing, Next-Generation Sequencing, and Bioinformatics Analyses}

The rapid evolution of cultivation-independent, next-generation sequencing, and meta-omics technologies has allowed for the integration and analyses of large datasets for the study of the diversity, complexity, and functional role of the human gut microbiome in health and disease [131]. A large part of the detected bacteria has never been cultivated [132]. Therefore, an integrative approach using both metagenome and metabolomebased characterizations of the gut microbiome together with bioinformatics and statistical filters and algorithms can provide strain-level taxonomic resolution of the taxa present in microbiomes, assess the potential functions encoded by the microbial community and quantify the metabolic activities within a complex microbiome [133].

The various platforms and reference databases developed for the marker gene (16S rRNA), metagenomics, or metatranscriptomics analysis often use similar stepwise approaches (Figure 2) with different bioinformatic tools (DADA2, Deblur, Kraken, MEGAN, HUMAnN, metaSPAdes, MEGAHIT, QIIME, Mothur, and several R packages (vegan, microbiome, etc.). 


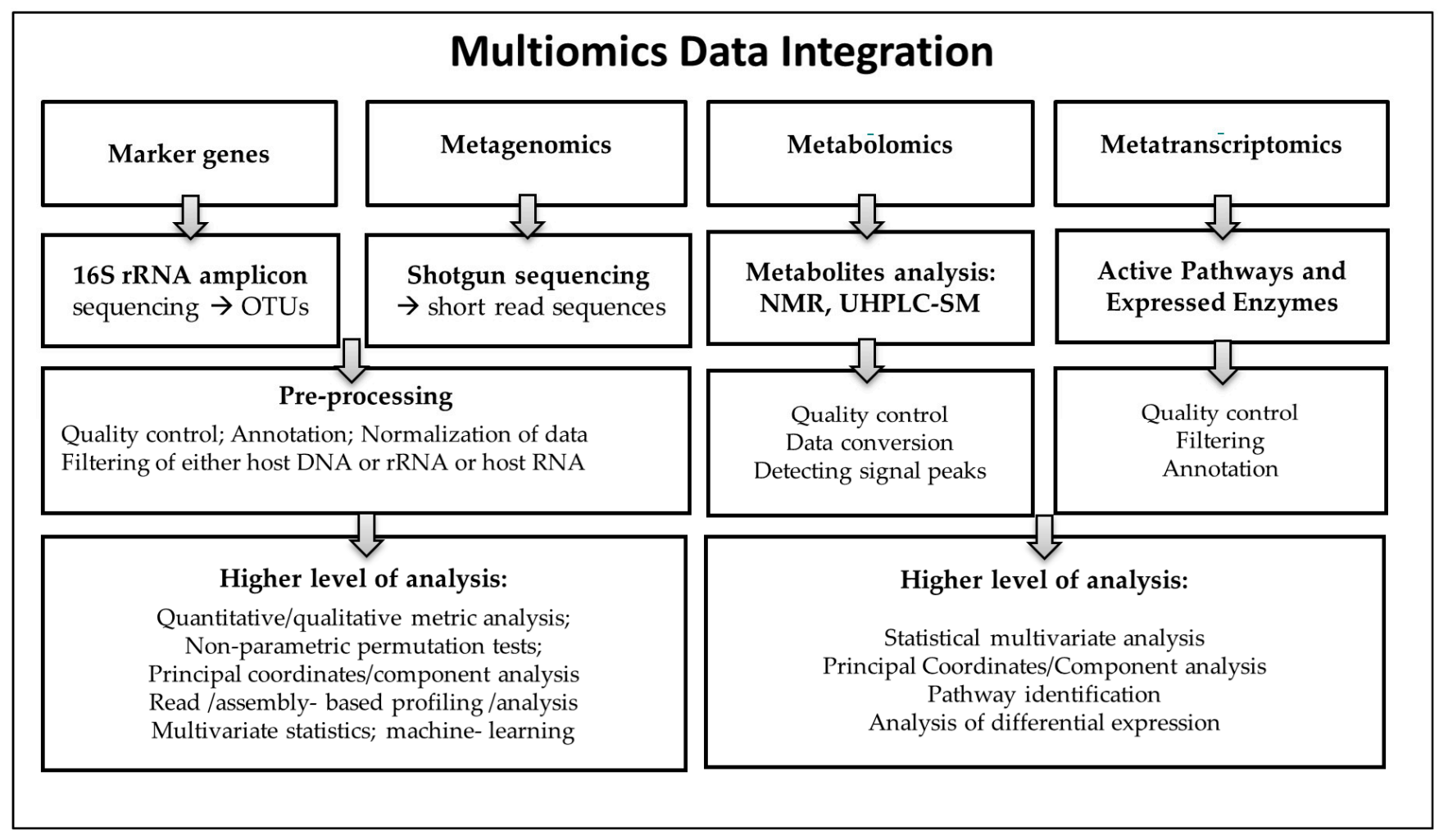

Figure 2. Multiomics and bioinformatics analysis of microbiome components.

\subsection{Omics Data Integration: Big Data and Host Clinical Responses}

As previously mentioned, microbiomics give us a great insight into the regulation of gut microbiota. However, in order to understand the complex biological pathways behind diseases, the identification of novel -omics biomarkers, such as identification of genes (genomics), gene expressions and phenotype (epigenomics), messenger RNA and micro RNA (transcriptomics), proteins (proteomics), and metabolites (metabolomics, lipidomics, glycomics) could bring forward knowledge on probiotics and their effects on obesity and its modulation of pathophysiological mechanisms that have links with chronic diseases [134,135].

Integrating multi-omics datasets is an innovative assignment, due to the increased complexity and diversity of the collected data [136]. This integration is increasingly reliant on efficient bioinformatics tools and advanced statistical methods [137-139]. Multi-omics data integration still poses challenges, but integration of multiple meta-omics datasets lays out a promising approach to comprehensively characterizing the composition, functional, and metabolic activity of microbiomes. This is of particular importance for microbiome research to be translated into clinical applications and further improvement of human health management [140].

\subsection{Safety Assessment, Regulatory Frameworks, and Market Labeling}

The overview of worldwide regulatory frameworks affecting different food categories is summarized in Table 5.

Overall, in the European Union (EU), most bacteria that will be used in foods for human consumption need to comply with two different regulations [141,142], or if used as life biotherapeutic products, as clarified in the European Pharmacopoeia (Ph. Eur.) [143]. At the same time, in the US, probiotics should be classified as microorganisms with a qualification of "generally recognized as safe" (GRAS) by the Food and Drug Administration (FDA). Both regulatory frameworks largely involve scientific requirements [14]. Furthermore, in order to assess the safety of microorganisms, the European Food Safety Authority (EFSA) introduced the concept of qualified presumption of safety (QPS) to harmonize the safety 
evaluation of microorganisms used as food or feed additives, food enzymes, novel foods, or pesticides, which has to follow certain criteria [144].

Table 5. Summary of probiotics categorization and regulation frameworks worldwide.

\begin{tabular}{|c|c|c|c|c|}
\hline Country & Category & $\begin{array}{l}\text { Regulatory } \\
\text { Framework }\end{array}$ & Claims & Reference \\
\hline \multirow[t]{5}{*}{ USA } & $\begin{array}{l}\text { Drugs, } \\
\text { nutraceuticals }\end{array}$ & FDA & $\begin{array}{l}\text { Health claims } \\
\text { Nutrient claims } \\
\text { Structure claims } \\
\text { GRAS }\end{array}$ & \multirow{5}{*}[145,146]{} \\
\hline & Dietary supplements & DSHEA & Probiotics considered as foods & \\
\hline & Biological product & FDA (BLA) & $\begin{array}{l}\text { Probiotics as a reference product, biosimilar product, } \\
\text { or an interchangeable product; solely to be used for } \\
\text { medical therapeutic purpose }\end{array}$ & \\
\hline & $\begin{array}{l}\text { Life biotherapeutic } \\
\text { agent }\end{array}$ & FDA & $\begin{array}{l}\text { Probiotics as a biological product that contains live } \\
\text { organisms and is applicable to the prevention, } \\
\text { treatment, or cure of a disease or condition; } \\
\text { recombinant life biotherapeutic agent }\end{array}$ & \\
\hline & Medical Food & FDA/DSHA & $\begin{array}{l}\text { Probiotics specially formulated to be intended for } \\
\text { dietary management under supervision; medical } \\
\text { foods are exempt from the labeling requirements for } \\
\text { nutrient content and health claims }\end{array}$ & \\
\hline China & Functional foods & SFDA & $\begin{array}{l}\text { Conventional foods mark (the presence of a specific } \\
\text { ingredient in the label of regular foodstuffs) } \\
\text { Healthy foods (the presence of health function) }\end{array}$ & [147] \\
\hline \multirow[t]{2}{*}{ Europe } & $\begin{array}{l}\text { Functional Food and } \\
\text { nutraceuticals }\end{array}$ & EFSA (FUFOSE) & $\begin{array}{l}\text { Health claims, nutrition claims } \\
\text { QPS }\end{array}$ & {$[143,144,148]$} \\
\hline & $\begin{array}{l}\text { Life biotherapeutic } \\
\text { products }\end{array}$ & EMA & $\begin{array}{l}\text { Probiotics as medicinal products containing live } \\
\text { microorganisms for human use }\end{array}$ & \\
\hline Japan & $\begin{array}{l}\text { Functional foods and } \\
\text { nutraceuticals }\end{array}$ & MHLW, FOSHU & $\begin{array}{l}\text { Foods with functional claims } \\
\text { Foods with nutrient functional claims }\end{array}$ & {$[149,150]$} \\
\hline Canada & $\begin{array}{l}\text { Natural health } \\
\text { products }\end{array}$ & FDA (CFIA) & $\begin{array}{l}\text { Nutrient content claims } \\
\text { Health claims }\end{array}$ & [151] \\
\hline
\end{tabular}

EFSA: European Food Safety Agency; EMA: European Medicines Agency; FAO/WHO: Food and Agricultural Organization/World Health Organization; MHLW: Ministry of Health and Welfare; FOSHU: food for specified health use; FUFOSE: functional food science in Europe; SFDA: State Food and Drug Administration; DSHEA: Dietary Supplement Health and Education Act; BLA: biologic license application; CFIA: the Canadian Food Inspection Agency.

However, despite all preventive effects, the consumption of probiotics may not be completely safe in certain cases or physiological states [14]. In this context, several bacterial species comprising genera other than Lactobacillus and Bifidobacterium with proven efficacy, which are considered as potential NGP, may be strain-by-strain assessed in order to obtain sufficient research data, and to grant probiotic status on the species and strain levels [152].

Information of beneficial results provided by the NGP will encompass comprehensive understanding of their targeted diseases. On top of these, the underlying molecular mechanisms on how NGP work and interact with the host have to be clarified [153]. It is important to characterize in vitro bacterial physiology, genomic analysis of potential virulence and antimicrobial resistance genes, investigations on the presence or absence of potential genes involved in transferring antibiotic resistance gene, and in vivo acute toxicity studies in both healthy and immunosuppressed mice [154].

The regulation of marketed probiotics applies differently among countries according to their classifications, and the country's nutritional and dietary habits and lifestyle. Therefore, probiotics can be classified as nutraceuticals, dietary supplements, or food. Regulation and requirements for the safety assessment of beneficial microbes is variable 
within countries [155-158]. Probiotics, food supplements, labeling and other information to consumers are regulated under the legislation $[159,160]$. On the opposite side, the US and its FDA, responsible for quality control of probiotics, has taken the approach of having minimal regulation [161]. Most probiotic products in the US are classified as food or dietary supplements, which have to comply with good manufacturing practice (GMP) guidelines [162]. Harmonization and consensus of all stakeholders involved in the probiotic market could be important since boundaries between differently regulated markets have become minimal [144].

Therefore, next-generation beneficial microbes' approval procedures should be enforced according to their classifications [154-159], stating the general safety of the product and using harmonized descriptions: the genus, species, and strains used, the CFU/g or $\mathrm{mL}$ of product (colony-forming units), the recommended use, and the daily dose; as well as quality and market parameters of the products: trademarks, formulae, ingredients, expiration dates, and storage conditions [151].

\section{Discussion}

The use of fermented food containing beneficial microbes is an ancestral tradition. Moreover, classical probiotics have been administered in several disorders and also specifically in obesity and metabolic diseases. However, they do not always provide harmonized endpoints data [136]. Controversial results have triggered the continuous need for searching and elucidating how to better understand and optimize the use and consumption information of probiotics. The combined impact of differential diets and the complementary probiotic strains should be standardized according to the individual and their microbiota composition and status [130]. Moreover, tested administration patterns and robust evidence of probiotics' clinical beneficial impact should be well-supported by clinical trials [14].

Therefore, NGP as well as the described new beneficial microbial species and strains [10] constitute a growing trend of searching for biotechnological uses. NGP could be considered as a complementary, preventive and/or therapeutic tool for standardized interventional clinical studies [48,49]. However, NGP searching strategies, culturing research, and clinical implementation still face challenges, and there are specific gaps to be covered regarding bioinformatics and statistical analysis, safety assessment, specific strains, and the frame regulation on marketing and labeling [145-148]. Regarding the bioinformatics analysis, the limitations are related to the capabilities of the different platforms used. Statistical analysis faced problems of high dimensionality, over-dispersion, sparsity, and zero-inflation of data. Safety assessments lack proven efficacy at species level (in vitro test; genomic analysis for identifying potential virulence and antimicrobial resistance genes; in vivo acute toxicity tests), while the regulations frame lacks global harmonization and consensus from all stakeholders involved in the probiotics market, together with clear, reliable, and truthful labeling, focusing specifically on the level of genus, species, and strain used in the product. The label should clearly state the genus, species, and strain used, CFU/g or $\mathrm{mL}$ of product (colony-forming units), and the recommended use and daily dose. Moreover, it should refer to the quality parameters and market conditions [151].

More standardization efforts and research intervention strategies should focus on modulatory microbiota capacities and envisage the development and use of NGP, the formulation of which requires competent preclinical studies to show their efficacy and safety status. In overall terms, such advances and directions could help researchers, clinicians, dietitians, and nutritionists in using harmonized probiotics supplementary recommendations and targeted effects. Moreover, a joint effort to incentivize the reuse of published clinical data as open access (OA) [163] will make available more data for robust comparisons.

Next-generation probiotics are emerging microorganisms with demonstrated clinical impact, well-defined modes of actions, and specific functions impacting target diseases. The microbiota of healthy individuals appeared enriched in microorganisms considered 
NGP such as A. muciniphila, F. prausnitzii, Eubacterium spp., within other several species that seem to contribute to a balanced intestinal microbiota [48,49]. Interestingly, these same species were lower in obesity-related disorders. Thus, the present work has focused on searching and culturing approaches for other profiled and decreased levels of microbial species in metabolic diseases.

Specific approaches for obtaining specific NGP that neutralize dietary obesogens and their effects have been discussed.

\section{Conclusions}

Therefore, the present work highlights the taxa culturing pathways and key topics for extrapolating and aligning investigation efforts on searching for NGP to target diseases where the interventional modulation studies of microbiota impact on health status. The present work allowed us to highlight the following needs and conclusions:

- Culturing of microorganisms from microbiota is the key activity to obtain NGP from healthy individuals, mainly through isolating those microorganisms identified as differentially decreased in the target disease or abundant in healthy microbiota, focusing on candidatus species from metagenomics studies.

- Screening and selection of the potential NGP in a target-disease population by using in vitro models before clinical interventions.

- Harmonization on performing exhaustive pre-analysis and post-intervention of individual microbiota composition through representative and validated methodologies (e.g., V3-V4 and Illumina MiSeq technology) is needed before administering NGP.

- There is a need to standardize bioinformatics and database tools for specifically designing analysis of large and universal microbiome datasets.

- NGP single strains or taxa consortium should have attributable documented benefits and their safety confirmation statements.

- Effective doses and well-defined patterns of administration of NGP should become factors for aligning intervention doses since the beginning of clinical translation.

- International guidelines on NGP and microbiota investigations for targeting obesityrelated diseases prevention or treatments are needed. This will allow for more meaningful effect comparisons of harmonized and valuable studies, facilitating more robust meta-analysis.

- Data reuse and availability of open access interventional clinical trials data will contribute to obtaining significant association of clinical outcomes.

Author Contributions: Conceptualization, A.L.-M., and M.A.; Methodology, all authors; WritingOriginal Draft Preparation, A.L.-M., I.A., K.C., and M.A.; Writing-Review and Editing; M.A.; Supervision, M.A. and A.S.; Project Administration, M.A.; Funding Acquisition, M.A. All authors have read and agreed to the published version of the manuscript.

Funding: This work was carried out within the frame of GP/EFSA/ENCO/380 2018/03/G04: OBEMIRISK: Knowledge platform for assessing the risk of Bisphenols on gut microbiota and its role in obesogenic phenotype: looking for biomarkers. This research was also funded by FEDERInfrastructure: IE_2019-198. A.L-M Incentivación de la Investigación. Plan Propio-UGR. K. Cerk is collaborating with UGR under the EU-FORA Programme (2020/2021).

Institutional Review Board Statement: Not applicable.

Informed Consent Statement: Not applicable.

Data Availability Statement: The data presented in this study are available in the article or supplementary material.

Acknowledgments: Part of the results are from Ana López-Moreno doctoral thesis, Biomedicine Doctorate Program and Inmaculada Acuña doctoral thesis, Nutrition and Food Technology Doctorate Program of the University of Granada.

Conflicts of Interest: The authors declare no conflict of interest. 


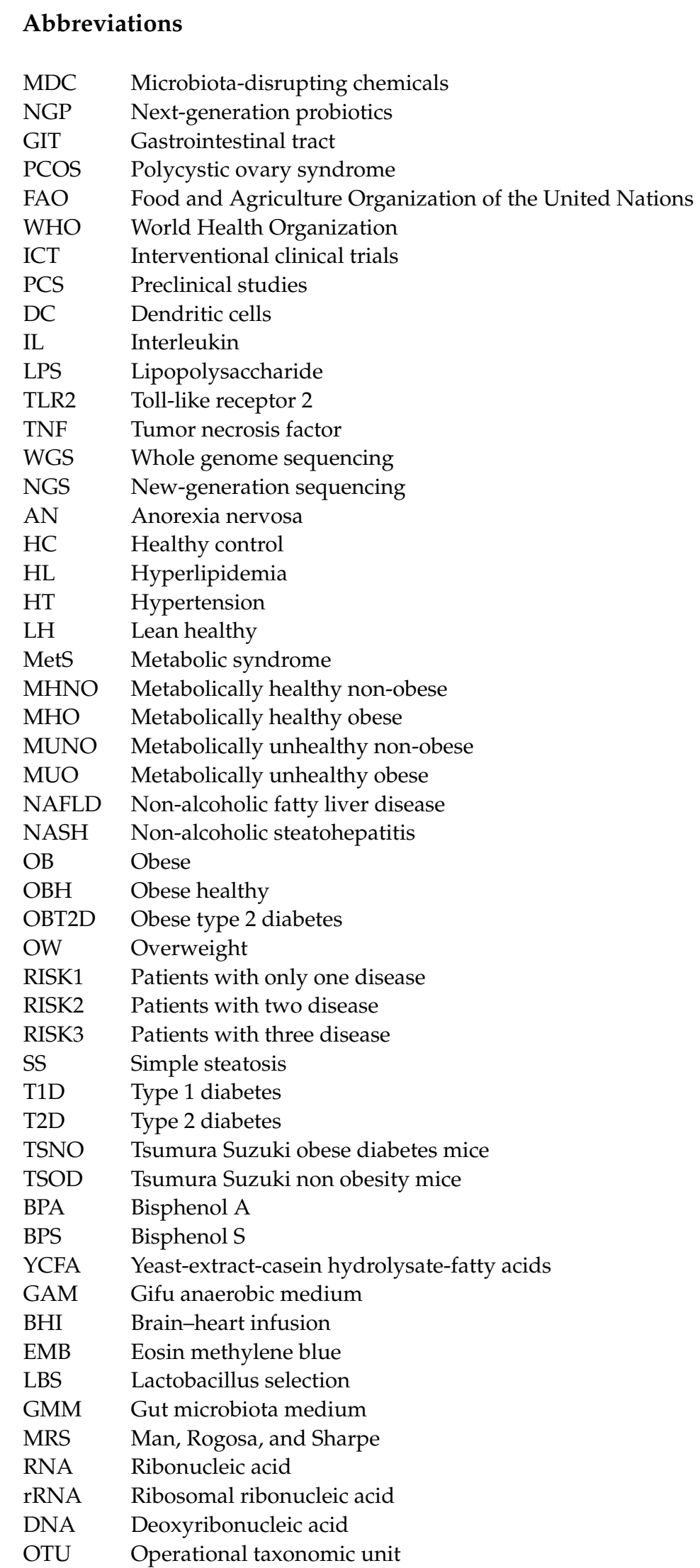




$\begin{array}{ll}\text { EU } & \text { European Union } \\ \text { Ph. Eur. } & \text { European Pharmacopoeia } \\ \text { US } & \text { United States } \\ \text { GRAS } & \text { Generally recognized as safe } \\ \text { FDA } & \text { Food and Drug Administration } \\ \text { EFSA } & \text { European Food Safety Authority } \\ \text { QPS } & \text { Qualified presumption of safety } \\ \text { EMA } & \text { European Medicines Agency } \\ \text { MHLW } & \text { Ministry of Health and Welfare } \\ \text { FOSHU } & \text { Food for specified health use } \\ \text { FUFOSE } & \text { Functional food science in Europe } \\ \text { SFDA } & \text { State Food and Drug Administration } \\ \text { DSHEA } & \text { Dietary Supplement Health and Education Act } \\ \text { BLA } & \text { Biologic license application } \\ \text { CFIA } & \text { The Canadian Food Inspection Agency } \\ \text { GMP } & \text { Good manufacturing practice } \\ \text { CFU } & \text { Colony-forming units } \\ \text { OA } & \text { Open access }\end{array}$

\section{References}

1. Katsi, V.; Didagelos, M.; Skevofilax, S.; Armenis, I.; Kartalis, A.; Vlachopoulos, C.; Karvounis, H.; Tousoulis, D. GUT MicrobiomeGUT dysbiosis-arterial hypertension: New horizons. Curr. Hypertens. Rev. 2019, 15, 40-46. [CrossRef] [PubMed]

2. Daliri, E.B.-M.; Lee, B.H. New perspectives on probiotics in health and disease. Food Sci. Hum. Wellness 2015, 4, 56-65. [CrossRef]

3. Ohkusa, T.; Koido, S.; Nishikawa, Y.; Sato, N. Gut microbiota and chronic constipation: A review and update. Front. Med. 2019, 6, 19. [CrossRef] [PubMed]

4. Matsuoka, K.; Kanai, T. The gut microbiota and inflammatory bowel disease. Semin. Immunopathol. 2015, 37, 47-55. [CrossRef] [PubMed]

5. dos Santos, C.; Ferreira, K.; Midori, P.; Fábio, L.; Darrieux, M.; Manzano, T. Childhood obesity and Firmicutes/Bacteroidetes ratio in the gut microbiota: A systematic review. Child. Obes. 2018, 14, 501-509. [CrossRef]

6. $\quad$ Liang, Y.; Ming, Q.; Liang, J.; Zhang, Y.; Zhang, H.; Shen, T. Gut microbiota dysbiosis in Polycystic Ovary Syndrome: Association with obesity-a preliminary report. Can. J. Physiol. Pharm. 2020, 98, 803-809. [CrossRef] [PubMed]

7. Meng, C.; Bai, C.; Brown, T.D.; Hood, L.E.; Tian, Q. Human gut microbiota and gastrointestinal cancer. Genom. Proteom. Bioinform. 2018, 16, 33-49. [CrossRef]

8. Bear, T.L.K.; Dalziel, J.E.; Coad, J.; Roy, N.C.; Butts, C.A.; Gopal, P.K. The role of the gut microbiota in dietary interventions for depression and anxiety. Adv. Nutr. 2020, 11, 890-907. [CrossRef]

9. Food and Agriculture Organization; World Health Organization Expert Consultation. Evaluation of Health and Nutritional Properties of Powder Milk and Live Lactic Acid Bacteria. Córdoba, Argentina: Food and Agriculture Organization of the United Nations and World Health Organization. 2001. Available online: ftp:/ /ftp.fao.org/es/esn/food/probio_report_en.pdf (accessed on 8 February 2021).

10. Chang, C.-J.; Lin, T.-L.; Tsai, Y.-L.; Wu, T.-R.; Lai, W.-F.; Lu, C.-C.; Lai, H.-C. Next Generation Probiotics in disease amelioration. J. Food Drug Anal. 2019, 27, 615-622. [CrossRef]

11. Tan, H.; Zhai, Q.; Chen, W. Investigations of Bacteroides spp. towards next-generation probiotics. Food Res. Int. 2019, 116, 637-644. [CrossRef]

12. Azaïs-Braesco, V.; Bresson, J.L.; Guarner, F.; Corthier, G. Not All Lactic Acid Bacteria Are Probiotics, but Some Are. Br. J. Nutr. 2010, 103, 1079-1081. [CrossRef] [PubMed]

13. Rijkers, G.T.; de Vos, W.M.; Brummer, R.-J.; Morelli, L.; Corthier, G.; Marteau, P. Health Benefits and Health Claims of Probiotics: Bridging Science and Marketing. Br. J. Nutr. 2011, 106, 1291-1296. [CrossRef] [PubMed]

14. O'Toole, P.W.; Marchesi, J.R.; Hill, C. Next-Generation Probiotics: The spectrum from probiotics to live biotherapeutics. Nat. Microbiol. 2017, 2, 17057. [CrossRef] [PubMed]

15. Zheng, J.; Wittouck, S.; Salvetti, E.; Franz, C.; Harris, H.; Mattarelli, P.; O’Toole, P.; Pot, B.; Vandamme, P.; Walter, J.; et al. A taxonomic note on the genus Lactobacillus: Description of 23 novel genera, emended description of the genus Lactobacillus Beijerinck 1901, and union of Lactobacillaceae and Leuconostocaceae. Int. J. Syst. Evol. Microbiol. 2020, 70, 2782-2858. [CrossRef] [PubMed]

16. Aller, R.; De Luis, D.A.; Izaola, O.; Conde, R.; Gonzalez, S.M.; Primo, D.; De La Fuente, B.; Gonzalez, J. Effect of a probiotic on liver aminotransferases in nonalcoholic fatty liver disease patients: A double blind randomized clinical trial. Eur. Rev. Med. Pharm. Sci. 2011, 15, 1090-1095.

17. Nagata, S.; Chiba, Y.; Wang, C.; Yamashiro, Y. The effects of the Lactobacillus casei strain on obesity in children: A pilot study. Benef. Microbes 2017, 8, 535-543. [CrossRef] 
18. Kim, J.; Yun, J.M.; Kim, M.K.; Kwon, O.; Cho, B. Lactobacillus gasseri BNR17 supplementation reduces the visceral fat accumulation and waist circumference in obese adults: A randomized, double-blind, placebo-controlled trial. J. Med. Food 2018, $21,454-461$. [CrossRef]

19. Tenorio-Jiménez, C.; Martínez-Ramírez, M.J.; Tercero-Lozano, M.; Arraiza-Irigoyen, C.; Del Castillo-Codes, I.; Olza, J.; Plaza-Díaz, J.; Fontana, L.; Migueles, J.H.; Olivares, M.; et al. Evaluation of the effect of Lactobacillus Reuteri V3401 on biomarkers of inflammation, cardiovascular risk and liver steatosis in obese adults with metabolic syndrome: A randomized clinical trial (PROSIR). BMC Complement. Altern. Med. 2018, 18, 306. [CrossRef]

20. Sánchez, M.; Darimont, C.; Drapeau, V.; Emady-Azar, S.; Lepage, M.; Rezzonico, E.; Ngom-Bru, C.; Berger, B.; Philippe, L.; Ammon-Zuffrey, C.; et al. Effect of Lactobacillus rhamnosus CGMCC1.3724 supplementation on weight loss and maintenance in obese men and women. Br. J. Nutr. 2014, 111, 1507-1519. [CrossRef]

21. Park, S.-S.; Lee, Y.-J.; Song, S.; Kim, B.; Kang, H.; Oh, S.; Kim, E. Lactobacillus acidophilus NS1 attenuates diet-induced obesity and fatty liver. J. Endocrinol. 2018, 237, 87-100. [CrossRef]

22. Yang, G.; Hong, E.; Oh, S.; Kim, E. Non-Viable Lactobacillus Johnsonii JNU3402 protects against diet-induced obesity. Foods 2020 9, 1494. [CrossRef]

23. Lee, E.; Jung, S.-R.; Lee, S.-Y.; Lee, N.-K.; Paik, H.-D.; Lim, S.-I. Lactobacillus plantarum strain Ln4 attenuates diet-induced obesity, insulin resistance, and changes in hepatic mrna levels associated with glucose and lipid metabolism. Nutrients 2018, 10, 643. [CrossRef]

24. Park, D.-Y.; Ahn, Y.-T.; Park, S.-H.; Huh, C.-S.; Yoo, S.-R.; Yu, R.; Sung, M.-K.; McGregor, R.A.; Choi, M.-S. Supplementation of Lactobacillus curvatus HY7601 and Lactobacillus plantarum KY1032 in diet-induced obese mice is associated with gut microbial changes and reduction in obesity. PLoS ONE 2013, 8, e59470. [CrossRef]

25. Wu, Y.; Li, X.; Tan, F.; Zhou, X.; Mu, J.; Zhao, X. Lactobacillus fermentum CQPC07 attenuates obesity, inflammation and dyslipidemia by modulating the antioxidant capacity and lipid metabolism in high-fat diet induced obese mice. J. Inflamm. 2021, 18, 5. [CrossRef] [PubMed]

26. Uusitupa, H.-M.; Rasinkangas, P.; Lehtinen, M.J.; Mäkelä, S.M.; Airaksinen, K.; Anglenius, H.; Ouwehand, A.C.; Maukonen, J. Bifidobacterium animalis Subsp. lactis 420 for metabolic health: Review of the research. Nutrients 2020, 12, 892. [CrossRef] [PubMed]

27. Minami, J.; Iwabuchi, N.; Tanaka, M.; Yamauchi, K.; Xiao, J.-Z.; Abe, F.; Sakane, N. Effects of Bifidobacterium breve B-3 on body fat reductions in pre-obese adults: A randomized, double-blind, placebo-controlled trial. Biosci. Microbiota Food Health 2018, 37, 67-75. [CrossRef]

28. Jones, R.B.; Alderete, T.L.; Martin, A.A.; Geary, B.A.; Hwang, D.H.; Palmer, S.L.; Goran, M.I. Probiotic supplementation increases obesity with no detectable effects on liver fat or gut microbiota in obese hispanic adolescents: A 16-Week, randomized, placebo-controlled trial. Pediatr. Obes. 2018, 13, 705-714. [CrossRef] [PubMed]

29. Bernini, L.J.; Simão, A.N.C.; de Souza, C.H.B.; Alfieri, D.F.; Segura, L.G.; Costa, G.N.; Dichi, I. Effect of Bifidobacterium lactis HN019 on inflammatory markers and oxidative stress in subjects with and without the metabolic syndrome. Br. J. Nutr. 2018, 120, 645-652. [CrossRef] [PubMed]

30. Schellekens, H.; Torres-Fuentes, C.; van de Wouw, M.; Long-Smith, C.M.; Mitchell, A.; Strain, C.; Berding, K.; Bastiaanssen, T.F.S.; Rea, K.; Golubeva, A.V.; et al. Bifidobacterium longum counters the effects of obesity: Partial successful translation from rodent to human. EBioMedicine 2021, 63, 103176. [CrossRef] [PubMed]

31. Lim, S.-M.; Kim, D.-H. Bifidobacterium adolescentis IM38 ameliorates High-Fat diet-induced colitis in mice by inhibiting nf-kb activation and lipopolysaccharide production by gut microbiota. Nutr. Res. 2017, 41, 86-96. [CrossRef]

32. Li, Z.; Jin, H.; Oh, S.Y.; Ji, G.E. Anti-Obese effects of two Lactobacilli and two Bifidobacteria on ICR mice fed on a high fat diet. Biochem. Biophys. Res. Commun. 2016, 480, 222-227. [CrossRef] [PubMed]

33. Sudha, M.R.; Ahire, J.J.; Jayanthi, N.; Tripathi, A.; Nanal, S. Effect of multi-strain probiotic (UB0316) in weight management in overweight/obese adults: A 12-Week Double Blind, Randomised, Placebo-Controlled Study. Benef. Microbes 2019, 10, 855-866. [CrossRef] [PubMed]

34. Wang, Y.; Wu, Y.; Wang, B.; Xu, H.; Mei, X.; Xu, X.; Zhang, X.; Ni, J.; Li, W. Bacillus amyloliquefaciens SC06 protects mice against high-fat diet-induced obesity and liver injury via regulating host metabolism and gut microbiota. Front. Microbiol. 2019, 10, 1161. [CrossRef] [PubMed]

35. Kim, B.; Kwon, J.; Kim, M.-S.; Park, H.; Ji, Y.; Holzapfel, W.; Hyun, C.-K. Protective Effects of Bacillus probiotics against high-fat diet-induced metabolic disorders in mice. PLOS ONE 2018, 13, e210120. [CrossRef] [PubMed]

36. Huang, J.; Huang, J.; Yin, T.; Lv, H.; Zhang, P.; Li, H. Enterococcus faecium R0026 combined with Bacillus subtilis R0179 prevent obesity-associated hyperlipidaemia and modulate gut microbiota in C57BL/6 Mice. J. Microbiol. Biotechnol 2020, 31, 181-188. [CrossRef]

37. Mishra, A.K.; Ghosh, A.R. Probiotic Enterococcus faecalis AG5 Mitigated high fat diet induced obesity and produced propionic acid stimulated apoptosis in 3T3-L1 pre-adipocyte. Life Sci. 2020, 261, 118292. [CrossRef]

38. Kang, X.; Liang, H.; Luo, Y.; Li, Z.; He, F.; Han, X.; Zhang, L. Anti-adipogenesis and metabolism-regulating effects of heatinactivated Streptococcus thermophilus MN-ZLW-002. Lett. Appl. Microbiol. 2020. [CrossRef] 
39. Everard, A.; Matamoros, S.; Geurts, L.; Delzenne, N.M.; Cani, P.D. Saccharomyces boulardii administration changes gut microbiota and reduces hepatic steatosis, low-grade inflammation, and fat mass in obese and Type 2 Diabetic Db/Db Mice. mBio 2014, 5, e01011-e01014. [CrossRef]

40. Zhang, J.; Xiao, X.; Dong, Y.; Shi, L.; Xu, T.; Wu, F. The anti-obesity effect of fermented barley extracts with Lactobacillus plantarum Dy-1 and Saccharomyces cerevisiae in diet-induced obese rats. Food Funct. 2017, 8, 1132-1143. [CrossRef]

41. Depommier, C.; Everard, A.; Druart, C.; Plovier, H.; Van Hul, M.; Vieira-Silva, S.; Falony, G.; Raes, J.; Maiter, D.; Delzenne, N.M.; et al. Supplementation with Akkermansia muciniphila in Overweight and Obese Human Volunteers: A Proof-of-Concept Exploratory Study. Nat. Med. 2019, 25, 1096-1103. [CrossRef]

42. ClinicalTrials.gov Unique Identifier: NCT04797442: Effect of Akkermansia muciniphila WST01 Strain in Overweight or Obese Patients with Type 2 Diabetes. Available online: https:/ / clinicaltrials.gov/ct2/show / NCT04797442 (accessed on 27 April 2021).

43. ClinicalTrials.gov Unique Identifier: NCT04663139: Xla1 Christensenella minuta, Phase I, Randomized, Partially Placebo-controlled Double-blind. Available online: https:/ / clinicaltrials.gov/ct2/show /NCT04663139 (accessed on 27 April 2021).

44. ClinicalTrials.gov Unique Identifier: NCT04529473: Efficacy and Safety of 12-weeks Supplementation of Eubacterium hallii on Insulin Sensitivity and Glycaemic Control. Available online: https:/ / linicaltrials.gov/ct2/ show / NCT04529473 (accessed on 27 April 2021).

45. Déchelotte, P.; Breton, J.; Trotin-Picolo, C.; Grube, B.; Erlenbeck, C.; Bothe, G.; Fetissov, S.O.; Lambert, G. The probiotic strain H. alvei HA4597 $\neg Æ$ improves weight loss in overweight subjects under moderate hypocaloric diet: A proof-of-concept, multicenter randomized, double-blind placebo-controlled study. Nutrients 2021, in press.

46. Beltrán-Barrientos, L.M.; Garcia, H.S.; Reyes-Díaz, R.; Estrada-Montoya, M.C.; Torres-Llanez, M.J.; Hernández-Mendoza, A.; González-Córdova, A.F.; Vallejo-Cordoba, B. Cooperation between Lactococcus lactis NRRL B-50571 and NRRL B-50572 for Aroma Formation in Fermented Milk. Foods 2019, 8, 645. [CrossRef] [PubMed]

47. Bazi, Z.; Jalili, M.; Hekmatdoost, A. The long term oral regulation of blood glucose in diabetic patients by using of Escherichia coli Nissle 1917 expressing CTB-IGF-1 hybrid protein. Med. Hypotheses 2013, 81, 961-962. [CrossRef]

48. Everard, A.; Belzer, C.; Geurts, L.; Ouwerkerk, J.P.; Druart, C.; Bindels, L.B.; Guiot, Y.; Derrien, M.; Muccioli, G.G.; Delzenne, N.M.; et al. Cross-Talk between Akkermansia muciniphila and intestinal epithelium controls diet-induced obesity. Proc. Natl. Acad. Sci. USA 2013, 110, 9066-9071. [CrossRef] [PubMed]

49. Cani, P.D.; de Vos, W.M. Next-Generation Beneficial Microbes: The case of Akkermansia muciniphila. Front. Microbiol. 2017, 8, 765. [CrossRef]

50. Shang, H.; Sun, J.; Chen, Y.Q. Clostridium butyricum CGMCC0313.1 modulates lipid profile, insulin resistance and colon homeostasis in obese mice. PLoS ONE 2016, 11, e0154373. [CrossRef]

51. Munukka, E.; Rintala, A.; Toivonen, R.; Nylund, M.; Yang, B.; Takanen, A.; Hänninen, A.; Vuopio, J.; Huovinen, P.; Jalkanen, S.; et al. Faecalibacterium prausnitzii treatment improves hepatic health and reduces adipose tissue inflammation in high-fat fed mice. ISME J. 2017, 11, 1667-1679. [CrossRef]

52. Cano, P.G.; Santacruz, A.; Moya, Á.; Sanz, Y. Bacteroides uniformis CECT 7771 ameliorates metabolic and immunological dysfunction in mice with high-fat-diet induced obesity. PLoS ONE 2012, 7, e41079. [CrossRef]

53. Wu, T.-R.; Lin, C.-S.; Chang, C.-J.; Lin, T.-L.; Martel, J.; Ko, Y.-F.; Ojcius, D.M.; Lu, C.-C.; Young, J.D.; Lai, H.-C. Gut commensal Parabacteroides goldsteinii plays a predominant role in the anti-obesity effects of polysaccharides isolated from Hirsutella sinensis. Gut 2019, 68, 248-262. [CrossRef] [PubMed]

54. Goodrich, J.K.; Waters, J.L.; Poole, A.C.; Sutter, J.L.; Koren, O.; Blekhman, R.; Beaumont, M.; Van Treuren, W.; Knight, R.; Bell, J.T.; et al. Human genetics shape the gut microbiome. Cell 2014, 159, 789-799. [CrossRef]

55. Engels, C.; Ruscheweyh, H.-J.; Beerenwinkel, N.; Lacroix, C.; Schwab, C. The common gut microbe eubacterium hallii also contributes to intestinal propionate formation. Front. Microbiol. 2016, 7, 713. [CrossRef]

56. Lucas, N.; Legrand, R.; Deroissart, C.; Dominique, M.; Azhar, S.; Le Solliec, M.-A.; Léon, F.; do Rego, J.-C.; Déchelotte, P.; Fetissov, S.O.; et al. Hafnia alvei HA4597 strain reduces food intake and body weight gain and improves body composition, glucose, and lipid metabolism in a mouse model of hyperphagic obesity. Microorganisms 2019, 8, 35. [CrossRef]

57. Ma, Y.; Liu, J.; Hou, J.; Dong, Y.; Lu, Y.; Jin, L.; Cao, R.; Li, T.; Wu, J. Oral administration of recombinant Lactococcus lactis expressing HSP65 and tandemly repeated P277 reduces the incidence of type i diabetes in non-obese diabetic mice. PLoS ONE 2014, 9, e105701. [CrossRef]

58. Ma, J.; Li, C.; Wang, J.; Gu, J. Genetically engineered Escherichia coli Nissle 1917 Secreting GLP-1 analog exhibits potential antiobesity effect in high-fat diet-induced obesity mice. Obesity 2020, 28, 315-322. [CrossRef] [PubMed]

59. Gomes, A.C.; Hoffmann, C.; Mota, J.F. The Human Gut Microbiota: Metabolism and perspective in obesity. Gut Microbes 2018, 9 , 308-325. [CrossRef] [PubMed]

60. Riva, A.; Borgo, F.; Lassandro, C.; Verduci, E.; Morace, G.; Borghi, E.; Berry, D. pediatric obesity is associated with an altered gut microbiota and discordant shifts in Firmicutes populations. Environ. Microbiol. 2017, 19, 95-105. [CrossRef] [PubMed]

61. Munukka, E.; Wiklund, P.; Pekkala, S.; Völgyi, E.; Xu, L.; Cheng, S.; Lyytikäinen, A.; Marjomäki, V.; Alen, M.; Vaahtovuo, J.; et al. Women with and without metabolic disorder differ in their gut microbiota composition. Obesity 2012, 20, 1082-1087. [CrossRef]

62. Bervoets, L.; Van Hoorenbeeck, K.; Kortleven, I.; Van Noten, C.; Hens, N.; Vael, C.; Goossens, H.; Desager, K.N.; Vankerckhoven, V. Differences in gut microbiota composition between obese and lean children: A cross-sectional study. Gut Pathog. $2013,5,10$. [CrossRef] 
63. Santacruz, A.; Collado, M.C.; García-Valdés, L.; Segura, M.T.; Martín-Lagos, J.A.; Anjos, T.; Martí-Romero, M.; Lopez, R.M.; Florido, J.; Campoy, C.; et al. Gut microbiota composition is associated with body weight, weight gain and biochemical parameters in pregnant women. Br. J. Nutr. 2010, 104, 83-92. [CrossRef]

64. Collado, M.C.; Isolauri, E.; Laitinen, K.; Salminen, S. Distinct composition of gut microbiota during pregnancy in overweight and normal-weight women. Am. J. Clin. Nutr. 2008, 88, 894-899. [CrossRef]

65. Schwiertz, A.; Taras, D.; Schäfer, K.; Beijer, S.; Bos, N.A.; Donus, C.; Hardt, P.D. Microbiota and SCFA in lean and overweight healthy subjects. Obesity 2010, 18, 190-195. [CrossRef]

66. Zhong, X.; Harrington, J.M.; Millar, S.R.; Perry, I.J.; O'toole, P.W.; Phillips, C.M. Gut microbiota associations with metabolic health and obesity status in older adults. Nutrients 2020, 12, 2364. [CrossRef] [PubMed]

67. Jonduo, M.E.; Wawae, L.; Masiria, G.; Suda, W.; Hattori, M.; Takayasu, L.; Abdad, M.Y.; Greenhill, A.R.; Horwood, P.F.; Pomat, W.; et al. Gut microbiota composition in obese and non-obese adult relatives from the highlands of Papua New Guinea. Microbiol. Lett. 2020, 367, 19. [CrossRef] [PubMed]

68. Thingholm, L.B.; Rühlemann, M.C.; Koch, M.; Fuqua, B.; Laucke, G.; Boehm, R.; Bang, C.; Franzosa, E.A.; Hübenthal, M.; Frost, F.; et al. Obese Individuals with and without Type 2 Diabetes Show Different Gut Microbial Functional Capacity and Composition. Cell Host Microbe 2019, 26, 252-264.e10. [CrossRef] [PubMed]

69. Gao, R.; Zhu, C.; Li, H.; Yin, M.; Pan, C.; Huang, L.; Kong, C.; Wang, X.; Zhang, Y.; Qu, S.; et al. Dysbiosis Signatures of Gut Microbiota Along the Sequence from Healthy, Young Patients to Those with Overweight and Obesity. Obesity 2018, 26, 351-361. [CrossRef] [PubMed]

70. Armougom, F.; Henry, M.; Vialettes, B.; Raccah, D.; Raoult, D. Monitoring bacterial community of human gut microbiota reveals an increase in Lactobacillus in obese patients and Methanogens in anorexic patients. PLoS ONE 2009, 4, 1-8. [CrossRef] [PubMed]

71. Horie, M.; Miura, T.; Hirakata, S.; Hosoyama, A.; Sugino, S.; Umeno, A.; Murotomi, K.; Yoshida, Y.; Koike, T. Comparative analysis of the intestinal flora in type 2 diabetes and nondiabetic mice. Exp. Anim. 2017, 66, 405-416. [CrossRef]

72. Larsen, N.; Vogensen, F.K.; Van Den Berg, F.W.J.; Nielsen, D.S.; Andreasen, A.S.; Pedersen, B.K.; Al-Soud, W.A.; Sørensen, S.J.; Hansen, L.H.; Jakobsen, M. Gut microbiota in human adults with type 2 diabetes differs from non-diabetic adults. PLoS ONE 2010, 5, e9085. [CrossRef]

73. Sedighi, M.; Razavi, S.; Navab-Moghadam, F.; Khamseh, M.E.; Alaei-Shahmiri, F.; Mehrtash, A.; Amirmozafari, N. Comparison of gut microbiota in adult patients with type 2 diabetes and healthy individuals. Microb. Pathog. 2017, 111, 362-369. [CrossRef]

74. Moghadam, F.; Sedighi, M.; Khamseh, M.E.; Alaei-Shahmiri, F.; Talebi, M.; Razavi, S.; Amirmozafari, N. The association of type II diabetes with gut microbiota composition. Microb. Pathog. 2017, 110, 630-636. [CrossRef]

75. Ahmad, A.; Yang, W.; Chen, G.; Shafiq, M.; Javed, S.; Zaidi, S.S.A.; Shahid, R.; Liu, C.; Bokhari, H. Analysis of gut microbiota of obese individuals with type 2 diabetes and healthy individuals. PLoS ONE 2019, 14, 1-15. [CrossRef] [PubMed]

76. Ejtahed, H.S.; Hoseini-Tavassol, Z.; Khatami, S.; Zangeneh, M.; Behrouzi, A.; Ahmadi, B.S.; Moshiri, A.; Hasani-Ranjbar, S.; Soroush, A.R.; Vaziri, F.; et al. Main gut bacterial composition differs between patients with type 1 and type 2 diabetes and non-diabetic adults. J. Diabetes Metab. Disord. 2020, 19, 265-271. [CrossRef] [PubMed]

77. Takagi, T.; Naito, Y.; Kashiwagi, S.; Uchiyama, K.; Mizushima, K.; Kamada, K.; Ishikawa, T.; Inoue, R.; Okuda, K.; Tsujimoto, Y.; et al. Changes in the gut microbiota are associated with hypertension, hyperlipidemia, and type 2 diabetes mellitus in Japanese subjects. Nutrients 2020, 12, 2996. [CrossRef] [PubMed]

78. Wang, B.; Jiang, X.; Cao, M.; Ge, J.; Bao, Q.; Tang, L.; Chen, Y.; Li, L. Altered fecal microbiota correlates with liver biochemistry in nonobese patients with non-alcoholic fatty liver disease. Sci. Rep. 2016, 6, 1-11. [CrossRef] [PubMed]

79. Li, F.; Sun, G.; Wang, Z.; Wu, W.; Guo, H.; Peng, L.; Wu, L.; Guo, X.; Yang, Y. Characteristics of fecal microbiota in non-alcoholic fatty liver disease patients. Sci. China Life Sci. 2018, 61, 770-778. [CrossRef] [PubMed]

80. Shen, F.; Zheng, R.; Sun, X.; Ding, W.; Wang, X.; Fan, J. Gut microbiota dysbiosis in patients with nonalcoholic fatty liver disease. Hepatobiliary Pancreat. Dis. Int. 2017, 16, 375-381. [CrossRef]

81. Raman, R.M.; Ahmed, I.; Gillevet, P.M.; Probert, C.S.; Ratcliffe, N.M.; Smith, S.; Greenwood, R.; Sikaroodi, M.; Lam, V.; Crotty, P.; et al. Fecal microbiome and volatile organic compound metabolome in obese humans with nonalcoholic fatty liver disease. Clin. Gastroenterol. Hepatol. 2013, 11, 868-875.e3. [CrossRef]

82. Michail, S.; Lin, M.; Frey, M.R.; Fanter, R.; Paliy, O.; Hilbush, B.; Reo, N.V. Altered gut microbial energy and metabolism in children with non-alcoholic fatty liver disease. FEMS Microbiol. Ecol. 2015, 91, 1-9. [CrossRef]

83. Nistal, E.; de Miera, L.E.S.; Pomar, M.B.; Sánchez-Campos, S.; García-Mediavilla, M.V.; Álvarez-Cuenllas, B.; Linares, P.; Olcoz, J.L.; Arias-Loste, M.T.; García-Lobo, J.M.; et al. An altered fecal microbiota profile in patients with non-alcoholic fatty liver disease (NAFLD) associated with obesity. Rev. Española Enferm. Dig. 2019, 111, 275-282. [CrossRef]

84. Loomba, R.; Seguritan, V.; Li, W.; Long, T.; Klitgord, N.; Bhatt, A.; Dulai, P.S.; Caussy, C.; Bettencourt, R.; Highlander, S.K.; et al. Gut microbiome based metagenomic signature for non-invasive detection of advanced fibrosis in human nonalcoholic fatty liver disease. Cell Metab. 2017, 25, 1054-1062. [CrossRef]

85. Del Chierico, F.; Nobili, V.; Vernocchi, P.; Russo, A.; De Stefanis, C.; Gnani, D.; Furlanello, C.; Zandonà, A.; Paci, P.; Capuani, G.; et al. Gut microbiota profiling of pediatric nonalcoholic fatty liver disease and obese patients unveiled by an integrated meta-omics-based approach. Hepatology 2017, 65, 451-464. [CrossRef]

86. Da Silva, H.E.; Teterina, A.; Comelli, E.M.; Taibi, A.; Arendt, B.M.; Fischer, S.E.; Lou, W.; Allard, J.P. Nonalcoholic fatty liver disease is associated with dysbiosis independent of body mass index and insulin resistance. Sci. Rep. 2018, 8, 1-12. [CrossRef] 
87. Mouzaki, M.; Comelli, E.M.; Arendt, B.M.; Bonengel, J.; Fung, S.K.; Fischer, S.E.; Mcgilvray, I.D.; Allard, J.P. Intestinal microbiota in patients with nonalcoholic fatty liver disease. Hepatology 2013, 58, 120-127. [CrossRef] [PubMed]

88. Zhu, L.; Baker, S.S.; Gill, C.; Liu, W.; Alkhouri, R.; Baker, R.D.; Gill, S.R. Characterization of gut microbiomes in nonalcoholic steatohepatitis (NASH) patients: A connection between endogenous alcohol and NASH. Hepatology 2013, 57, 601-609. [CrossRef] [PubMed]

89. Boursier, J.; Mueller, O.; Barret, M.; Machado, M.; Fizanne, L.; Arauo-Perez, F.; Guy, C.D.; Seed, P.C.; Rawls, J.F.; David, L.A.; et al. The severity of NAFLD is associated with gut dysbiosis and shift in the metabolic function of the gut microbiota. Hepatology 2016, 63, 764-775. [CrossRef]

90. Qin, N.; Yang, F.; Li, A.; Prifti, E.; Chen, Y.; Shao, L.; Guo, J.; Le Chatelier, E.; Yao, J.; Wu, L.; et al. Alterations of the human gut microbiome in liver cirrhosis. Nature 2014, 513, 59-64. [CrossRef] [PubMed]

91. Lim, M.Y.; You, H.J.; Yoon, H.S.; Kwon, B.; Lee, J.Y.; Lee, S.; Song, Y.M.; Lee, K.; Sung, J.; Ko, G. The effect of heritability and host genetics on the gut microbiota and metabolic syndrome. Gut 2017, 66, 1031-1038. [CrossRef] [PubMed]

92. Arumugam, M.; Raes, J.; Pelletier, E.; Le Paslier, D.; Yamada, T.; Mende, D.R.; Fernandes, G.R.; Tap, J.; Bruls, T.; Batto, J.-M.; et al. Enterotypes of the Human Gut Microbiome. Nature 2011, 473, 174-180. [CrossRef]

93. Singh, R.K.; Chang, H.-W.; Yan, D.; Lee, K.M.; Ucmak, D.; Wong, K.; Abrouk, M.; Farahnik, B.; Nakamura, M.; Zhu, T.H.; et al. Influence of Diet on the Gut Microbiome and Implications for Human Health. J. Transl. Med. 2017, 15, 73. [CrossRef]

94. David, L.A.; Maurice, C.F.; Carmody, R.N.; Gootenberg, D.B.; Button, J.E.; Wolfe, B.E.; Ling, A.V.; Devlin, A.S.; Varma, Y.; Fischbach, M.A.; et al. Diet Rapidly and Reproducibly Alters the Human Gut Microbiome. Nature 2014, 505, 559-563. [CrossRef]

95. De Filippis, F.; Pellegrini, N.; Vannini, L.; Jeffery, I.B.; La Storia, A.; Laghi, L.; Serrazanetti, D.I.; Di Cagno, R.; Ferrocino, I.; Lazzi, C.; et al. High-Level Adherence to a Mediterranean Diet Beneficially Impacts the Gut Microbiota and Associated Metabolome. Gut 2016, 65, 1812-1821. [CrossRef] [PubMed]

96. Qian, L.; Gao, R.; Hong, L.; Pan, C.; Li, H.; Huang, J.; Qin, H. Association analysis of dietary habits with gut microbiota of a native Chinese community. Exp. Ther. Med. 2018, 16, 856-866. [CrossRef]

97. Lim, M.Y.; Rho, M.; Song, Y.-M.; Lee, K.; Sung, J.; Ko, G. Stability of Gut Enterotypes in Korean Monozygotic Twins and Their Association with Biomarkers and Diet. Sci. Rep. 2014, 4, 7348. [CrossRef] [PubMed]

98. Patra, J.K.K.; Das, G.; Paramithiotis, S.; Shin, H.-S. Kimchi and Other Widely Consumed Traditional Fermented Foods of Korea: A Review. Front. Microbiol. 2016, 7, 1493. [CrossRef] [PubMed]

99. Woo, H.D.; Shin, A.; Kim, J. Dietary Patterns of Korean Adults and the Prevalence of Metabolic Syndrome: A Cross-Sectional Study. PLoS ONE 2014, 9, e111593. [CrossRef]

100. Dimidi, E.; Cox, S.R.; Rossi, M.; Whelan, K. Fermented Foods: Definitions and Characteristics, Impact on the Gut Microbiota and Effects on Gastrointestinal Health and Disease. Nutrients 2019, 11, 1806. [CrossRef]

101. Eshel, G.; Shepon, A.; Makov, T.; Milo, R. Land, irrigation water, greenhouse gas, and reactive nitrogen burdens of meat, eggs, and dairy production in the United States. Proc. Natl. Acad. Sci. USA 2014, 19, 11996-12001. [CrossRef]

102. Bergman, Å.; Becher, G.; Blumberg, B.; Bjerregaard, P.; Bornman, R.; Brandt, I.; Casey, S.; Frouin, H.; Giudice, L.; Heindel, J.; et al. Manufacturing doubt about endocrine disrupter science-A rebuttal of industry-sponsored critical comments on the UNEP/WHO report State of the Science of Endocrine Disrupting Chemicals 2012. Regul. Toxicol. Pharm. 2015, 73, 1007-1017. [CrossRef]

103. Claus, S.P.; Guillou, H.; Ellero-Simatos, S. The gut microbiota: A major player in the toxicity of environmental pollutants? NPJ Biofilms Microbiomes 2016, 2, 16003, Erratum in 2017, 22, 17001. [CrossRef]

104. Sharma, S.; Tripathi, P. Gut Microbiome and type 2 diabetes: Where we are and where to go? J. Nutr. Biochem. 2019, 63, 101-108. [CrossRef]

105. Aguilera, M.; Gálvez-Ontiveros, Y.; Rivas, A. Endobolome, a new concept for determining the influence of Microbiota Disrupting Chemicals (MDC) in relation to specific endocrine pathogenesis. Front. Microbiol. 2020, 11, 578007. [CrossRef] [PubMed]

106. Gálvez-Ontiveros, Y.; Páez, S.; Monteagudo, C.; Rivas, A. Endocrine Disruptors in Food: Impact on Gut Microbiota and Metabolic Diseases. Nutrients 2020, 12, 1158. [CrossRef] [PubMed]

107. Darbre, P. Endocrine disruptors and obesity. Curr. Obes. Rep. 2017, 6, 18-27. [CrossRef] [PubMed]

108. Vanhaecke, L.; Derycke, L.; Le Curieux, F.; Lust, S.; Marzin, D.; Verstraete, W.; Bracke, M. The microbial PhIP metabolite 7-hydroxy-5-methyl-3-phenyl-6,7,8,9-tetrahydropyrido $\left[3^{\prime}, 2^{\prime}: 4,5\right]$ imidazo [1,2-a]pyrimidin-5-ium chloride (PhIP-M1) induces DNA damage, apoptosis and cell cycle arrest towards Caco-2 cells. Toxicol. Lett. 2008, 178, 61-69. [CrossRef] [PubMed]

109. Carmody, R.N.; Turnbaugh, P.J. Host-microbial interactions in the metabolism of therapeutic and diet-derived xenobiotics. J. Clin. Investig. 2014, 124, 4173-4181. [CrossRef]

110. Kassie, F.; Laky, B.; Nobis, E.; Kundi, M.; Knasmüller, S. Genotoxic effects of methyl isothiocyanate. Mutat. Res. 2001, 490, 1-9. [CrossRef]

111. Zhang, X.; Gao, B.; Creamer, A.E.; Cao, C.; Li, Y. Adsorption of VOCs onto engineered carbon materials: A review. J. Hazard. Mater. 2017, 338, 102-123. [CrossRef]

112. Abdelsalam, N.A.; Ramadan, A.T.; El Rakaiby, M.T.; Aziz, R.K. Toxicomicrobiomics: The Human Microbiome vs. Pharmaceutical, Dietary, and Environmental Xenobiotics. Front. Pharm. 2020, 11, 390. [CrossRef]

113. Hayashi, H.; Sakamoto, M.; Benno, Y. Phylogenetic Analysis of the Human Gut Microbiota Using 16S RDNA Clone Libraries and Strictly Anaerobic Culture-Based Methods. Microbiol. Immunol. 2002, 46, 535-548. [CrossRef] 
114. Martínez, N.; Hidalgo-Cantabrana, C.; Delgado, S.; Margolles, A.; Sánchez, B. Filling the Gap between Collection, Transport and Storage of the Human Gut Microbiota. Sci. Rep. 2019, 9, 88. [CrossRef]

115. Stewart, E.J. Growing unculturable bacteria. J. Bacteriol. 2012, 194, 4151-4160. [CrossRef] [PubMed]

116. Lagier, J.-C.; Dubourg, G.; Million, M.; Cadoret, F.; Bilen, M.; Fenollar, F.; Levasseur, A.; Rolain, J.-M.; Fournier, P.-E.; Raoult, D. Culturing the Human Microbiota and Culturomics. Nat. Rev. Microbiol. 2018, 16, 540-550. [CrossRef] [PubMed]

117. López-Moreno, A.; Torres-Sánchez, A.; Acuña, I.; Suárez, A.; Aguilera, M. Representative Bacillus sp. AM1 from gut microbiota harbor versatile molecular pathways for Bisphenol A biodegradation. Int. J. Mol. Sci. 2021, 22, 4952. [CrossRef]

118. Browne, H.P.; Forster, S.C.; Anonye, B.O.; Kumar, N.; Neville, B.A.; Stares, M.D.; Goulding, D.; Lawley, T.D. Culturing of 'unculturable' human microbiota reveals novel taxa and extensive sporulation. Nature 2020, 533, 543-546. [CrossRef] [PubMed]

119. Chang, Y.; Hou, F.; Pan, Z.; Huang, Z.; Han, N.; Bin, L.; Deng, H.; Li, Z.; Ding, L.; Gao, H.; et al. Optimization of culturomics strategy in human fecal samples. Front. Microbiol. 2019, 10, 2891. [CrossRef] [PubMed]

120. Gotoh, A.; Nara, M.; Sugiyama, Y.; Sakanaka, M.; Yachi, H.; Kitakata, A.; Nakagawa, A.; Minami, H.; Okuda, S.; Katoh, T.; et al. Use of Gifu Anaerobic Medium for culturing 32 dominant species of human gut microbes and its evaluation based on short-chain fatty acids fermentation profiles. Biosci. Biotechnol. Biochem. 2017, 81, 2009-2017. [CrossRef] [PubMed]

121. Lagier, J.-C.; El Karkouri, K.; Mishra, A.K.; Robert, C.; Raoult, D.; Fournier, P.-E. Non contiguous-finished genome sequence and description of Enterobacter massiliensis sp. nov. Stand. Genom. Sci. 2013, 7, 399-412. [CrossRef]

122. Bailey, M.T.; Coe, C.L. Endometriosis is associated with an altered profile of intestinal microflora in female rhesus monkeys. Hum. Reprod. 2002, 17, 1704-1708. [CrossRef]

123. Lei, M.; Menon, R.; Manteiga, S.; Alden, N.; Hunt, C.; Alaniz, R.C.; Lee, K.; Jayaraman, A. Environmental chemical diethylhexyl phthalate alters intestinal microbiota community structure and metabolite profile in mice. Msystems 2019, 4, 00724-19. [CrossRef]

124. Williams, N.T. Probiotics. Am. J. Health Sys. Pharm. 2010, 67, 449-458. [CrossRef]

125. Farnworth, E.R. The evidence to support health claims for probiotics. J. Nutr. 2008, 138, 1250-1254. [CrossRef] [PubMed]

126. Ouwehand, A.C. A Review of Dose-Responses of Probiotics in Human Studies. Benef. Microbes 2017, 8, 143-151. [CrossRef] [PubMed]

127. Ouwehand, A.C.; Invernici, M.M.; Furlaneto, F.A.C.; Messora, M.R. Effectiveness of Multistrain Versus Single-Strain Probiotics: Current Status and Recommendations for the Future. J. Clin. Gastroenterol. 2018, 52 (Suppl. 1), S35-S40. [CrossRef]

128. López-Moreno, A.; Aguilera, M. Vaginal probiotics for reproductive health and related dysbiosis: Sistematic review and meta-analysis. J. Clin. Med. 2021, 1461. [CrossRef]

129. López-Moreno, A.; Suárez, A.; Avanzi, C.; Monteoliva-Sánchez, M.; Aguilera, M. Probiotic Strains and Intervention Total Doses for Modulating Obesity-Related Microbiota Dysbiosis: A Systematic Review and Meta-Analysis. Nutrients 2020, 12, 1921. [CrossRef]

130. Rijkers, G.T.; Bengmark, S.; Enck, P.; Haller, D.; Herz, U.; Kalliomaki, M.; Kudo, S.; Lenoir-Wijnkoop, I.; Mercenier, A.; Myllyluoma, E.; et al. Guidance for substantiating the evidence for beneficial effects of probiotics: Current status and recommendations for future research. J. Nutr. 2010, 140, 671S-676S. [CrossRef]

131. Miyoshi, J.; Rao, M.C.; Chang, E.B. Navigating the human gut microbiome: Pathway to success from lessons learned. Gastroenterology 2020, 159, 2019-2024. [CrossRef]

132. Amrane, S.; Hocquart, M.; Afouda, P.; Kuete, E.; Pham, T.P.T.; Dione, N.; Ngom, I.I.; Valles, C.; Bachar, D.; Raoult, D.; et al. Metagenomic and culturomic analysis of gut microbiota dysbiosis during Clostridium difficile infection. Sci. Rep. 2019, 9, 1-8. [CrossRef]

133. Dhakan, D.B.; Maji, A.; Sharma, A.K.; Saxena, R.; Pulikkan, J.; Grace, T.; Gomez, A.; Scaria, J.; Amato, K.R.; Sharma, V.K. The unique composition of Indian gut microbiome, gene catalogue, and associated fecal metabolome deciphered using multi-omics approaches. GigaScience 2019, 8, 1-20. [CrossRef]

134. Egidius, H.M.; Veidal, S.S.; Feigh, M.; Hallenborg, P.; Puglia, M.; Pers, T.H.; Vrang, N.; Jelsing, J.; Kornum, B.R.; Blagoev, B.; et al. Multi-omics characterization of a diet-induced obese model of non-alcoholic steatohepatitis. Sci. Rep. 2020, 10, 1148. [CrossRef]

135. Graw, S.; Chappell, K.; Washam, L.C.; Gies, A.; Bird, J.; Robeson, S.M.; Byrum, S.D. Multi-omics data integration considerations and study design for biological systems and disease. Mol. Omics 2021, 17, 170-185. [CrossRef]

136. Jiménez-Pranteda, M.L.; Pérez-Davó, A.; Monteoliva-Sánchez, M.; Ramos-Cormenzana, A.; Aguilera, M. Food Omics Validation: Towards Understanding Key Features for Gut Microbiota, Probiotics and Human Health. Food Anal. Methods 2015, 8, $272-289$. [CrossRef]

137. Valles-Colomer, M.; Darzi, Y.; Vieira-Silva, S.; Falony, G.; Raes, J.; Joossens, M. Meta-omics in inflammatory bowel disease research: Applications, challenges, and guidelines. J. Crohns. Colitis 2016, 10, 735-746. [CrossRef]

138. Mallick, H.; Bucci, V.; An, L. Experimental design and quantitative analysis of microbial community multiomics. Genome Biol. 2017, 18, 1-16. [CrossRef]

139. Knight, R.; Vrbanac, A.; Taylor, B.C.; Aksenov, A.; Callewaert, C.; Debelius, J.; Gonzalez, A.; Kosciolek, T.; McCall, L.I.; McDonald, D.; et al. Best practices for analysing microbiomes. Nat. Rev. Microbiol. 2018, 16, 410-422. [CrossRef]

140. Zhang, X.; Li, L.; Butcher, J.; Stintzi, A.; Figeys, D. Advancing functional and translational microbiome research using meta-omics approaches. Microbiome 2019, 7, 1-12. [CrossRef]

141. The European Parliament and the Council of the European Union. Regulation (EC) No $258 / 97$ of the European Parliament and of the Council of 27 January 1997 concerning novel foods and novel food ingredients. Off. J. Eur. Union 1997, 43, $0001-0006$. Available online: https: / / eur-lex.europa.eu/legal-content/EN/TXT/?uri=celex\%3A31997R0258 (accessed on 10 February 2021). 
142. The European Parliament and the Council of the European Union. Regulation (EC) No 1924/2006 of the European Parliament and the of the Council of 20 December 2006 on nutrition and health claims made on foods. Off. J. Eur. Union 2006, 404, 9-25. Available online: https: / / eur-lex.europa.eu/legal-content/en/ALL/?uri=CELEX\%3A32006R1924 (accessed on 10 February 2021).

143. Cordaillat-Simmons, M.; Rouanet, A.; Pot, B. Live biotherapeutic products: The importance of a defined regulatory framework. Exp. Mol. Med. 2020, 52, 1397-1406. [CrossRef]

144. Ricci, A.; Allende, A.; Bolton, D.; Chemaly, M.; Davies, R.; Girones, R.; Herman, L.; Koutsoumanis, K.; Lindqvist, R.; Nørrung, B.; et al. Scientific Opinion on the update of the list of QPS-recommended biological agents intentionally added to food or feed as notified to EFSA. EFSA J. 2017, 15, 3. [CrossRef]

145. United States Food and Drug Administration. Federal Food, Drug, and Cosmetic Act; United States Food and Drug Administration (FDA), 2018. Available online: http:/ / www.fda.gov/regulatoryinformation/legislation/federalfooddrugandcosmeticacfdcact/ default.htm/ (accessed on 10 March 2021).

146. Degnan, F.H. Clinical studies involving probiotics: When FDA's investigational new drug rubric applies-and when it may not. Gut Microbes 2012, 3, 485-489. [CrossRef]

147. Yang, M.S. Regulatory aspects of nutraceuticals: Chinese perspective. In Nutraceuticals, 1st ed.; Grumezescu, A., Ed.; Elsevier: New York, NY, USA, 2016; pp. 947-957.

148. de Simone, C. The Unregulated Probiotic Market. Clin. Gastroenterol. Hepatol. 2019, 17, 809-817. [CrossRef]

149. Amagase, H. Current marketplace for probiotics: A Japanese perspective. Clin. Infect. Dis. 2008, 46, 73-75. [CrossRef]

150. Nagata, J.; Yamada, K. Foods with Health Claims in Japan. Food Sci. Technol. Res. 2008, 14, 519-524. [CrossRef]

151. Arora, M.; Baldi, A. Comparative study of regulatory framework for probiotics: Current status and future recommendations. Appl. Clin. Res. Clin. Trials Regul. Aff. 2017, 4, 140-156. [CrossRef]

152. Hill, C.; Guarner, F.; Reid, G.; Gibson, G.R.; Merenstein, D.J.; Pot, B.; Morelli, L.; Canani, R.B.; Flint, H.J.; Salminen, S.; et al. Expert consensus document: The international scientific association for probiotics and prebiotics consensus statement on the scope and appropriate use of the term probiotic. Nat. Rev. Gastroenterol. Hepatol. 2014, 11, 506-514. [CrossRef]

153. Lin, T.L.; Shu, C.C.; Lai, W.F.; Tzeng, C.M.; Lai, H.C.; Lu, C.C. Investiture of next generation probiotics on amelioration of diseases-Strains do matter. Med. Microecol. 2019, 2, 100002. [CrossRef]

154. Saarela, M.H. Safety aspects of next generation probiotics. Curr. Opin. Food Sci. 2019, 30, 8-13. [CrossRef]

155. Morovic, W.; Roper, J.M.; Smith, A.B.; Mukerji, P.; Stahl, B.; Rae, J.C.; Ouwehand, A.C. Safety evaluation of HOWARU ${ }^{\circledR}$ Restore (Lactobacillus acidophilus NCFM, Lactobacillus paracasei Lpc-37, Bifidobacterium animalis subsp. lactis Bl-04 and B. lactis Bi-07) for antibiotic resistance, genomic risk factors, and acute toxicity. Food Chem. Toxicol. 2017, 110, 316-324. [CrossRef]

156. Li, B.; Zhan, M.; Evivie, S.E.; Jin, D.; Zhao, L.; Chowdhury, S.; Sarker, S.K.; Huo, G.; Liu, F. Evaluating the safety of potential probiotic Enterococcus durans KLDS6.0930 using whole genome sequencing and oral toxicity study. Front. Microbiol. 2018, 9, 1-15. [CrossRef]

157. The European Parliament; The Council of the European Union. Directive 2000/13/EC on the Approximation of the Laws of the Member States Relating to the Labelling, Presentation and Advertising of Foodstuffs. Off. J. Eur. Union 2000, 109, 29-42. Available online: https: / / eur-lex.europa.eu/legal-content/EN/ALL/?uri=celex\%3A32000L0013 (accessed on 10 February 2021).

158. The European Parliament; The Council of the European Union. Regulation (EU) No 1169/2011 of the European Parliament and of the Council of 25 October 2011 on the Provision of Food Information to Consumers, Amending Regulations (EC) No $1924 / 2006$ and (EC) No 1925/2006 of the European Parliament and of the Council, and Repealing Commission Directive 87/250/EEC, Council Directive 90/496/EEC, Commission Directive 1999/10/EC, Directive 2000/13/EC of the European Parliament and of the Council, Commission Directives 2002/67/EC and 2008/5/EC and Commission Regulation (EC) No 608/2004 Off. J. Eur. Union 2011, 27, 18-63. Available online: https:/ / eur-lex.europa.eu/legal-content/EN/ALL/?uri=CELEX\%3A32011R1169 (accessed on 10 February 2021).

159. Hoffmann, D.E. Health claim regulation of probiotics in the USA and the EU: Is there a middle way? Benef. Microbes 2013, 4, 109-115. [CrossRef]

160. International Probiotics Association. Best Practices Guidelines for Probiotics. Int. Probiotics Assoc. 2017, 1-4. Available online: http:/ /internationalprobiotics.org/wp-content/uploads/CRN-IPA-Best-Practices-Guidelines-for-Probiotics-final.pdf (accessed on 10 February 2021).

161. Reid, G.; Kort, R.; Alvarez, S.; Bourdet-Sicard, R.; Benoit, V.; Cunningham, M.; Saulnier, D.M.; Van Hylckama, V.J.E.T.; Verstraelen, H.; Sybesma, W. Expanding the reach of probiotics through social enterprises. Benef. Microbes 2018, 9, 707-715. [CrossRef]

162. International Scientific Association for Probiotics and Prebiotics. Probiotic Product Labels. Int. Sci. Assoc. Probiotics Prebiotics 2017. Available online: https: / isappscience.org/for-consumers/probiotic-product-labels/ (accessed on 10 February 2021).

163. Wang, J.; Pourang, A.; Burrall, B. Open access medical journals: Benefits and challenges. Clin. Derm. 2019, 37, 52-55. [CrossRef] 